\title{
Foreign language educators' exposure to research: reported experiences, exposure via citations, and a proposal for action
}

Article

Accepted Version

Marsden, E. and Kasprowicz, R. (2017) Foreign language educators' exposure to research: reported experiences, exposure via citations, and a proposal for action. The Modern Language Journal, 101 (4). pp. 613-642. ISSN 00267902 doi: https://doi.org/10.1111/modl.12426 Available at https://centaur.reading.ac.uk/79144/

It is advisable to refer to the publisher's version if you intend to cite from the work. See Guidance on citing.

To link to this article DOI: http://dx.doi.org/10.1111/modl.12426

Publisher: Wiley

All outputs in CentAUR are protected by Intellectual Property Rights law, including copyright law. Copyright and IPR is retained by the creators or other copyright holders. Terms and conditions for use of this material are defined in the End User Agreement.

www.reading.ac.uk/centaur 
Central Archive at the University of Reading

Reading's research outputs online 
Foreign Language Educators' Exposure to Research: Reported Experiences, Exposure Via Citations, and a Proposal for Action

\author{
EMMA MARSDEN,${ }^{1}$ and ROWENA KASPROWICZ ${ }^{2}$ \\ ${ }^{1}$ University of York, Centre for Research into Language Learning and Use, Department of \\ Education, York, YO10 5DD, United Kingdom Email: emma.marsden@york.ac.uk \\ ${ }^{2}$ University of York, Digital Creativity Labs, YO10 5DD, United Kingdom Email: \\ rowena.kasprowicz@york.ac.uk
}

\title{
$<$ A $>$ ABSTRACT
}

The article reports on two connected studies that provide data about the flow of research to foreign language educators in majority Anglophone contexts. The first study investigated exposure to research among FL educators in the UK using two surveys $(n=391 ; n=183)$. The data showed (a) some limited exposure to research via professional association publications and events, (b) negligible direct exposure to Social Science Citation Indexed (SSCI) publications, (c) barriers to exposure caused by poor physical and conceptual access, despite generally positive perceptions of research, and (d) the importance of university-based teacher educators for research-practice interfaces.

The second study investigated the potential for indirect exposure to research from seven professional publications over five years in Australia, the UK and the United States. We systematically reviewed the extent to which these professional publications referenced 29 SSCI journals that aim to publish pedagogy-relevant research. In our corpus of 8,516 references in 284 articles in professional journals, the mean proportion of references per article to all 29 SSCI journals, combined, was $12.43 \%$. The overall mean number of references to each SSCI journal was 0.17 per professional article.

The overall emerging picture is rather bleak, and we propose action from academic journals to promote a more international, systematic, and sustainable flow of research. 
<END OF ABSTRACT $>$

Keywords: perceptions of research; research-practice interface; consumption of research; citation; professional journals; teacher knowledge; teacher education 


\section{$<$ A $>$ BACKGROUND}

The desire to facilitate the flow of information between research and practice is well established among journal editors (via 'Aims and Scope' sections), researchers (via articles and books), research associations (via mission statements, conference themes, invited plenaries), teachers (via professional associations, journals, conferences), and policy-makers (via infrastructure, grey literature, schemes to incentivize researcherpractitioner communication). One way of enriching research-practice interfaces is via engaging practitioners in doing action, co-constructed or collaborative research, phenomena that have already received some attention. Another way, the focus of the current article, is via disseminating research - arguably the main pursuit of academic researchers. Very little empirical evidence exists about the extent and nature of teachers' and teacher educators' engagement with published research in the area of foreign language (FL) education in Anglophone contexts, despite much interest and investment in the potential relevance and applicability of research for practice. The current article begins to address this gap in two closely related studies: one investigating FL educators' direct contact with research via a survey of reported behaviours and perceptions in the UK; and another study investigating indirect contact with research via citation of the research in professional publications in Australia, the UK, and the United States.

We first present key arguments for practitioner engagement with research put forward by the research community and policy-makers. We then provide a short narrative review of the limited number of extant investigations into the extent and nature of practitioners' exposure to published research. 
Instructed second language acquisition (ISLA) researchers repeatedly espouse inherent links between research and pedagogy (Hellerman, 2015). A persistent desire to nurture these links is clear at research conferences and in many publications (e.g. Belcher, 2007; Collins \& Muñoz, 2016; Ellis, 2010, 2012; Lantolf \& Poehner, 2015; Larsen-Freeman, 2009, 2015; Lightbown, 2000; Macaro, 2003; Pachler, 2003; Spada, 2015), aspiring to a reciprocal relationship in which teachers critically engage with research evidence and researchers engage with practice throughout the research process, that is, opening up a twoway street. Research engagement has been found to develop teachers' sense of professional identity (Winch, Oancea, \& Orchard, 2015), offer insight into technical, practical, and theoretical aspects of pedagogical knowledge (Furlong et al., 2014), and provide new ways of seeing, doing, talking, knowing, and thinking (Borg, 2010, p. 414). Journal articles often suggest 'pedagogical implications', providing the opportunity for practitioners to assess the relevance of findings for their context (Chappelle, 2007; cf. Han 2007). Critical for the current study is that many academic journals explicitly state a mission to publish research of relevance to teaching. For example: Applied Linguistics (2016) states “Applied linguistics is viewed not only as the relation between theory and practice, but also as the study of language and language-related problems in specific situations in which people use and learn languages. ... the journal welcomes contributions in such areas of current enquiry as: . . first and additional language learning, teaching and use ...”; the Modern Language Journal (MLJ) (2016) includes an aim to "link the findings of research to teaching and learning in a variety of settings and on all educational levels"; Language Learning (2016) is concerned with "fundamental theoretical issues in language learning such as child, second, and foreign language acquisition, language education, literacy..."; and Studies in Second Language Acquisition (2016) contains "articles dealing with theoretical topics, some of which have broad pedagogical implication ...."1 
However, disparities between the pursuits and priorities of researchers and practitioners and a lack of interface between ISLA research and practice are frequently observed (Byrnes, 2016; Long, 2000). In some ways, publishing in academic journals serves only the academic community: For example, journal impact factors are academic performance indicators, displayed on journal homepages and used in university promotion systems. Consequently, journal articles are very often linguistically, conceptually, and/or physically inaccessible to practitioners (Borg, 2013; Byrnes, 2000; Ellis, 2010; Lantolf, 2000; Macaro, 2003; McNamara, 2002). Montgomery and Smith (2015) observed that teachers often "express frustration with how "out of touch" academic articles seem to be with the dayto-day realities of [classrooms]" (p. 100) and Shkedi (1998) reported Israeli teachers' lack of trust in research and the generalizations that are drawn, with perceptions such as "it's statistics, it's not reflective of reality" (p. 567). Kiely (2014) highlighted that "if teachers feel researchers do not understand their task in classroom teaching, they are unlikely to be persuaded to innovate or experiment" (p. 443). Probably as both a cause and a consequence of these issues, it has been argued that research is disseminated for peer researchers rather than practitioners (Montgomery \& Smith, 2015; Pachler, 2003).

However, we have very little concrete data about the actual impact of this "oftentimes noxious research versus teaching dichotomy" (Byrnes, 2016, p. 7). A crucial question, rarely empirically investigated yet tightly related to understanding and improving researchpractice relations, is the extent to which academic research finds (or has the potential to find) its way into the hands and minds of practitioners. The current study explored this topic by documenting direct and indirect exposure to (mainly written) academic research amongst language educators.

Our focus on written channels of communication therefore does not cover in detail all researcher-practitioner interfaces (e.g. professional development events). We also do not aim 
to cover practitioners' participation in action or co-constructed research and their developing cognition (e.g., Borg, 2003, Borg \& Sanchez, 2015, Burns 2011; Lantolf \& Poehner, 2015; Macaro, 2003); nor do we contribute to debates surrounding different conceptualisations of the roles and activities of FL teachers (Kubanyiova \& Crookes, 2016). Rather, we temporarily suspend such issues in order to provide data on the extent and manner in which research may reach FL educators in the first place.

\section{$<$ A $>$ TOP-DOWN INITIATIVES RELATING TO RESEARCH-PRACTICE INTERFACES}

Repeated calls for research-informed teaching and teacher training are also made from school education policy perspectives (e.g., Coates et al., 2011). For example, Carter (2015) highlighted that engagement with research should be part of teacher education and recommended a central, accessible database of world-leading research evidence (pp. 8-9), and Furlong et al. (2014) concluded that teachers and teacher educators should be discerning consumers of research (p. 5). Incentivisation for teachers to engage with published research is also apparent (DfE, 2016, p. 258, see also College of Teaching ${ }^{2}$ ).

In some contexts, governments establish ‘top-down' incentivisation for academics. For example, Australian, UK and US funding systems, along with some promotion structures, encourage academics to make their research meaningful to non-academic users, often referred to as 'impact' (e.g., the American Association of Applied Linguistics' Promotion and Tenure Guidelines, 2017; Australian Research Council (ARC), 2016; National Science Board, 2011; Research Excellence Framework (REF), 2011; Trounson, 2014). The aim is to facilitate and recognise the value of informing policy and practice and engaging non-academic users with research. However, these incentives largely relate to funding awarding mechanisms and do not directly incentivise the communication of individual academic studies, once completed, to non-academic users. For example, NSB (2011) included the principles that 'broader 
impacts' should be treated more like 'intellectual merit' and may be better measured beyond the individual project - at the institutional level for instance (Holbrook, 2012: 17). Overall, the importance of writing for academic audiences still far outweighs indicators of impact, and journal articles remain the main pursuit for the clear majority of academics (for discussion see e.g. Chubb \& Watermeyer, 2016; Holbrook \& Hrotic 2013).

In England, an additional confound is at play as attempts were made to devolve teacher education from universities to schools (Furlong et al., 2014; Universities UK, 2014). In 2015/2016, $51 \%$ of trainees in England followed school-led routes, compared to $33 \%$ in 2013/14 (DfE, 2015). This has compounded concerns about research-practice interfaces, at odds with calls for a research-informed profession (Beauchamp et al., 2015; Bell, 2015; Lawes, 2003; Macrory, 2015) and with best practice internationally (Sahlberg, 2010; Swain, 2014; Tatto, 2015). Thus, it is important to know, at least for contexts in which teacher education can be school-led, the extent of exposure to research among school-based teachers and how this compares to non-school-based teacher educators.

In sum, the extent to which academics' core activity (publishing) reaches FL practitioners is worthy of investigation and yet, as discussed next, we have little data on the topic.

\section{<A>LANGUAGE TEACHERS' 'CONSUMPTION' OF RESEARCH}

The flow of research findings has rarely been empirically investigated, with a "dearth of systematic surveys" (Leat, Reid, \& Lofthouse, 2015, p. 271). In educational research, teachers' engagement with research has received some attention (e.g., Bell et al., 2010; Cordingley, 2015). This has provided data about broad types of sources that teachers draw on, for example, in-service training, colleagues, reading material such as subject association publications (Ratcliffe, 2004; Williams \& Coles, 2007); practitioner materials, assessments, 
classroom observations (Montgomery \& Smith, 2015; Pachler, 2003), and social media (Sanders et al., 2005). However, these do not tell us about the use of sources in which published research is discussed (Leat et al., 2015, p. 271), about the extent and nature of exposure, or about FL education specifically.

Several initiatives have aimed to boost teacher engagement with research, though their focus is often on general educational issues such as classroom management, socioeconomic factors, ability grouping (e.g., in the UK, see the National Teacher Research Panel, CURREE ${ }^{4}$ and National Foundation for Education Research; in the US, see the Great Lakes Centre for Education Research and Practice, and the What Works Clearing House). Often vulnerable to the political climate and without a sustained infrastructure, most initiatives have a relatively short shelf-life. ${ }^{5}$ Specific to language education, the research-practitioner infrastructure 'Centre for Information on Language Teaching and Research' closed its national centres in England in 2010 and in Wales in 2015, with centres currently remaining in Scotland and Northern Ireland. Graham and Macaro's regional FL Professional Development Consortium stands out as a rare but fine example of research reaching practitioners, mainly through face to face network events funded in $2012-2015 .{ }^{6}$ In the United States, the Title VI Language Resource Centres, the Centre for Applied Linguistics and the Modern Language Association's Digital Commons (https://digitalpedagogy.mla.hcommons.org/) provide many research-practice interfaces. Of relevance here, however, is that we could not locate data about the extent to which such initiatives provide links between academic publications and FL (non-English) school teachers.

A number of studies by Borg $(2007,2010,2013)$ have explored ELT practitioners' engagement with research. In an international survey of 1,160 ESL/EFL teachers, Borg (2010) found that $75 \%$ reported reading about research at least "sometimes" (p. 412). As Borg acknowledges, although a promising figure, the frequency and nature of reading remain 
unclear. Also, we do not know how well these findings extend to non-English FL practitioners. Contextual differences may be significant as (a) ELT professionals have many regional, national, and international associations (e.g., IATEFL, SEETA, TESOL), and (b) research on English as an L2/FL is more extensive than on any other single language (Collins \& Muñoz, 2016; Plonsky, 2013).

In sum, although we are aware of a range of barriers that hinder engagement with research, the extent or severity of their impact is unclear. We do not have data about (a) the extent to which FL teachers and teacher educators are exposed to material that mentions or directly reports research, (b) the nature of publications they read, or (c) what those publications, in turn, cite. As a consequence, we have a poor understanding about the flow of internationally peer-reviewed research from journals that claim relevance to instruction, either in terms of FL educators' direct exposure (via reading such research) or indirect exposure (via citation of research in publications that they read).

\section{$<$ A $>$ AIMS}

To begin to address these gaps, this study falls into two parts. Part 1 reports the results of a survey of UK FL practitioners' access to material that mentions or reports research. Part 2 reports on a systematic review of references in FL practitioner publications in the UK and two other Anglophone contexts. Together, the aims were to document: (a) the amount and nature of research that school-based and non-school-based UK FL practitioners report reading or hearing about, (b) the factors that UK practitioners' report hinder engagement with research, (c) the extent to which practitioner journals in the UK, Australia, and the United States reference published academic research. 


\section{$<B>$ Methods}

Two online surveys were administered: the 'full survey' (approximately 20 minutes), and a shorter version with three questions adapted from the full survey (approximately 1-2 minutes, henceforth 'short survey'). The short survey was administered in addition to the full survey in order to (a) gather data from more respondents for a subset of our key issues, and (b) elicit data about respondents' experiences and behaviours in the last 12 months, whereas the full survey asked respondents for estimations of total experiences and behaviour to date. $<C>$ Participants. Our respondents all worked in the area of school (primary and secondary, ages 5-18) FL education in the UK, with a total final $n$ of 183 respondents to the full survey and 391 to the short survey. The $n$ for each subsection of the surveys varied due to some in-survey attrition (Appendix C).

The surveys elicited respondents' main place of work and length of experience (Appendix D). For analyses, respondents were divided into two groups based on their Position (main role): School-Based practitioners (SB), who spent a majority of their time in the classroom teaching FLs; and Non-School-Based practitioners (NSB), who spent the majority of their time outside the classroom. Of the 48 NSB in the full survey, 42 (87.5\%) were university-based teacher educators and $6(12.5 \%)$ consultants or advisors. Of the 110 NSB in the short survey, $72(65.5 \%)$ were university-based teacher educators and $38(34.5 \%)$ consultants or advisors. Population size is difficult to estimate, but to give some indication we found internet records for 62 university-based teacher educators in the UK who deliver a FL Post-Graduate Certificate of Education, primary or secondary, suggesting a very high NSB response rate.

$<C>$ The Survey Instruments. Most survey items were determined by the specific behaviours we wished participants to report on, with response scales about frequency that we deemed answerable and appropriate for analysis. The items eliciting attitudes towards barriers 
to research engagement used 0-100 sliding scales to allow expression of nuanced attitudes, and because it was difficult to express isolated intermediate categories as in a Likert-type scale. Although such data is not strictly interval data, it is equally, and arguably more, informative compared to scales with, say, five response categories. The survey underwent informal piloting with a small number of teachers. We acknowledge that the items pertaining to attitudes (latent variables), in particular, should have been more rigorously piloted. Although our principle component analysis contributes to our understanding of instrument validity to some extent, we hope others will use our materials (found at www.irisdatabase.org) to further investigate their validity and reliability.

First, the term 'research' was defined very clearly at the start of both surveys, and at various points throughout as an aide-memoire, as: "Systematic activity, that goes beyond $\underline{\text { normal }}$ teaching duties, and that aims to shed light on a particular phenomenon" [original emphasis]. 'Research related activities' were defined as "reading, listening to, discussing, and doing research." However, we acknowledge that the term remained open to some individual interpretation, as with any self-report technique.

The current article focuses on two groups of items in the full survey (Appendix A). The first group related to the amount and nature of research that respondents reported being exposed to, both in written and face-to-face formats. The written formats named by respondents were coded into three types: (a) SSCI journals (Thomson-Reuters, 2016); (b) practitioner-focused /non-SSCI journals; (c) magazines /newsletters / reports (d) other. Events were coded as: (a) professional subject association (e.g. Association for Language Learning, ALL), (b) local school cluster, (c) local authority, (d) university-based, and (e) other.

The second group of items in the full survey asked respondents to "rate the extent to which [14] factors prevent you from engaging in (more) research activities", on a sliding 
scale from 0 (does not prevent me at all) to 100 (prevents me very much indeed).

Respondents were also asked to indicate "in your opinion, is the research that you are aware of relevant to everyday classroom practice?" by selecting "Not at all relevant", "Somewhat relevant", or "Very relevant".

The short survey had three closed response items (Appendix B). Two questions asked respondents approximately how many times in the last 12 months "you have read or heard (1) something that mentions (i.e., refers indirectly to) research (e.g. newspapers, professional magazines etc.)"; and (2) "an original research report (i.e., a study written or presented by those who did the research"). The third question asked respondents to "rate the extent to which [7] factors prevent you from engaging in (more) research activities" using a sliding scale from 0 (does not prevent me at all) to 100 (prevents me very much indeed).

$<C>$ Administration of the Surveys. The surveys were administered via Qualtrics and disseminated via: UK practitioner associations (ALL, Network for Languages); email forums (CfBT, ITET-Languages ${ }^{7}$ ); practitioner events (Language World, ITET in London); and, social media (Facebook, Twitter).

$<C>$ Analysis. Descriptive data (means, standard deviations, medians, ranges) were calculated. Cohen's $d$ effect sizes are given for paired comparisons, ${ }^{8}$ and interpreted relative to Plonsky \& Oswald's (2014) general benchmarks for within- and between-subject comparisons in second language research. Nominal data were analysed using a Chi-square test of Independence, with Position (SB or NSB) as an independent variable. The data relating to factors hindering engagement were analysed using Principal Components Analysis (PCA) in order to reduce the items into a smaller number of variables (Conway \& Huffcutt, 2003). ${ }^{9}$ Both datasets were deemed suitable for PCA, since the ratio of variables to participants (full survey, $k=14, n=162$; short survey, $k=7, n=333$ ) was within most recommended ranges (Plonsky \& Gonulal, 2015) and KMO statistics were sufficiently large 
(full survey, $\mathrm{KMO}=.788$; short survey, $\mathrm{KMO}=.741$ ). Bartlett's test of sphericity indicated a significant level of correlation between items for each dataset (Field, 2013). We retained all components with eigenvalues $>1$. An oblique (specifically, a direct oblimin) factor rotation was applied so that each item loaded maximally onto just one of the components (new variables) extracted. An overall percentage rating for each new variable per respondent was calculated as follows: ${ }^{10}$

$$
=\frac{\left.\sum \text { (Ratings for items within new variable }\right)}{(\text { Total possible rating })} \times 100
$$

A Multiple Analysis of Variance (MANOVA) was then used to compare the respondents' ratings across the new variables based on their Position (SB/NSB).

The two surveys overlapped in their aims but we changed some of the items in the short survey, cutting or simplifying to obtain a higher $n$. As the surveys were administered anonymously online, we could not guarantee complete independence of data (some respondents may have responded to both surveys, even though we asked them not to). For these reasons the two datasets were analysed separately throughout. However, for ease of interpretation results are presented here thematically (rather than the results of each survey presented sequentially).

$<B>$ Results

$<C>$ Hearing About Research at Face-to-Face Events. Respondents were asked for details about the number and name of "conferences and professional development events where some research was presented" (Table 1). NSB reported attending statistically significantly more events than $\mathrm{SB}(U=5016.00, z=6.476, p=.001, d=1.28$, a large between-subject effect). 


\section{TABLE 1}

Number of Events Ever Attended Where Research was Presented (Full Survey)

\begin{tabular}{ccccccc} 
Position & $\mathrm{N}$ & $\mathrm{M}$ & $\mathrm{SD}$ & $\mathrm{Mdn}$ & $\mathrm{Min}$ & $\mathrm{Max}$ \\
\hline $\mathrm{SB}$ & 131 & 3.05 & 3.56 & 2 & 0 & 18 \\
\hline NSB & 47 & 8.62 & 5.05 & 9 & 0 & 21 \\
\hline
\end{tabular}

Table 2 shows the extent to which participants reported having attended at least one event where research was presented. A third of SB reported never having heard about any research at a face to face event.

Respondents named 330 events, which consisted of 123 unique events (coded into types in Appendix E). The most frequently mentioned - accounting for 30.3\%-were the national subject association's events. Research conferences were rarely mentioned: the British Association for Applied Linguistics, the European Second Language Association, and the British Education Research Association made up 3.3\% of the total mentions, all made by nine out of the 42 university-based teacher educators surveyed.

\section{TABLE 2}

Exposure to Research via Event Attendance and Reading (Full Survey) 
Have you ever...

\begin{tabular}{rccccccc} 
& & $\begin{array}{c}\text { attended a conference or } \\
\text { CPD event where research } \\
\text { was presented? }\end{array}$ & $\begin{array}{c}\text { read about research in a } \\
\text { professional magazine / } \\
\text { newsletter? }\end{array}$ & \multicolumn{2}{c}{$\begin{array}{c}\text { read about research in a } \\
\text { journal? }\end{array}$} \\
\cline { 2 - 7 } & & Yes & No & Yes & No & Yes & No \\
\hline SB & $\mathbf{N}$ & 90 & 45 & 106 & 29 & 54 & 81 \\
& $\%$ & 66.7 & 33.3 & 78.5 & 21.5 & 40 & 60 \\
\hline NSB & $\mathbf{N}$ & 44 & 4 & 44 & 4 & 35 & 13 \\
& $\%$ & 91.7 & 8.3 & 91.7 & 8.3 & 72.9 & 27.1 \\
\hline Chi-square & $\chi^{2}(1)=11.288, p=.001$ & $\chi^{2}(1)=4.141, p=.042$ & $\chi^{2}(1)=15.358, p=.001$ \\
\hline
\end{tabular}

$<C>$ Reading About Research. Table 2 also shows the extent to which respondents reported reading documents that mention research and reading original research reports, with NSB reporting statistically significantly more of both types than SB. Over half our SB and approximately a quarter of NSB had never read an original research report. Table 3 specifies the average number of articles read ${ }^{11}$, with NSB reporting significantly more articles than SB $(U=5041.00, z=5.760, p=.001, d=1.18$, a large effect $)$.

\section{TABLE 3}

Mean Reported Number of Articles Ever Read in Magazines/Newsletters and Journals (Full Survey)

\begin{tabular}{rcccccc} 
Position & $N$ & $M$ & $S D$ & Mdn & Min & Max \\
\hline SB & 135 & 9.12 & 8.40 & 8 & 0 & 32 \\
NSB & 48 & 25.97 & 18.45 & 24 & 0 & 64
\end{tabular}

Note. $\mathrm{SB}=$ School-Based practitioners; NSB $=$ Non-School-based practitioners.

The short survey results were broadly consistent with the full survey data (see Figure 1). Just over a third of SB reported that over the last 12 months they had read or heard between zero and 5 times something that mentioned research. A quarter of SB and about a half of NSB reported having read or heard something 20 or more times that mentioned 
research. In terms of reading or hearing an original account of research, 70\% of SB reported zero to two, whereas 55\% of NSB reported 6 or more. Again, there were statistical relationships between Position and exposure to material that mentioned research $\left(\chi^{2}(5)=\right.$ $38.014, p=.001)$ and to original research reports $\left(\chi^{2}(1)=4.141, p=.042\right)$.

\section{FIGURE 1}

Reported Exposure in Last 12 Months (Short Survey)
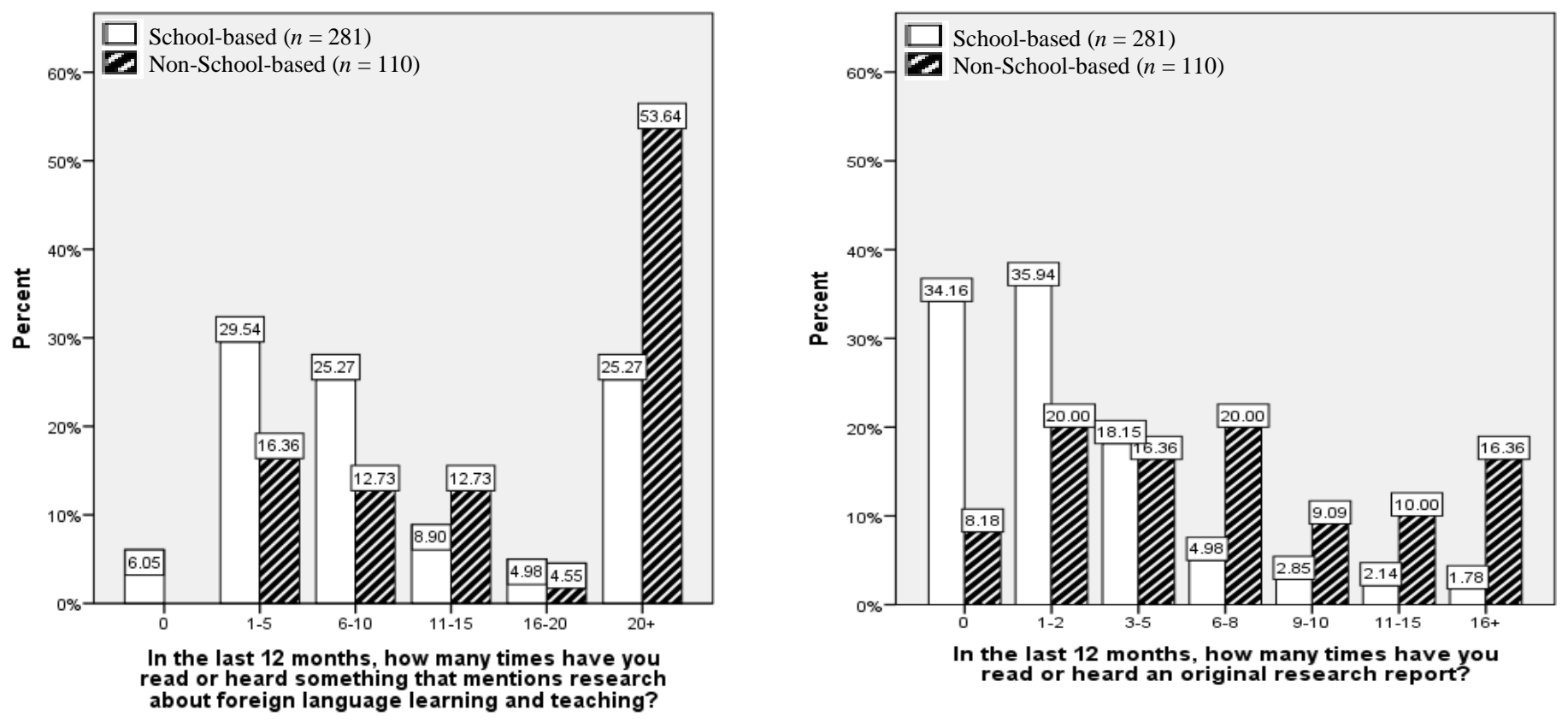

Across all participants ( $N=183$, Full Survey), there were 357 mentions (raw counts) of having read about research, spanning 105 unique publications. The overwhelming majority $(83.76 \%)$ of publications were either magazines / newsletters / reports $(41.18 \%)$ or practitioner-focussed / non-SSCI journals (42.58\%). The most frequently mentioned publication was The Language Learning Journal, the official journal of the subject association, accounting for $16.81 \%$ of all mentions. Table 4 shows the 10 most frequently mentioned publications, which included three SSCI journals, each accounting for $1-2 \%$ of the mentions. 


\section{TABLE 4}

Ten Most Frequently Mentioned Publications (full survey)

\begin{tabular}{|c|c|c|c|}
\hline Publication & Type & $\begin{array}{c}\text { \# of } \\
\text { mentions }\end{array}$ & $\%$ \\
\hline Language Learning Journal & practitioner / non-SSCI journal $^{12}$ & 60 & 16.81 \\
\hline $\begin{array}{r}\text { Times (Higher) Educational } \\
\text { Supplement }\end{array}$ & magazine / newsletter / report & 40 & 11.20 \\
\hline ALL publications ${ }^{a}$ & practitioner / non-SSCI journal & 40 & 11.20 \\
\hline Languages Today & magazine / newsletter / report & 37 & 10.36 \\
\hline Francophonie & practitioner / non-SSCI journal & 17 & 4.76 \\
\hline $\begin{array}{r}\text { (Scottish) Centre for Information on } \\
\text { Language Teaching }\end{array}$ & magazine / newsletter / report & 8 & 2.24 \\
\hline The Modern Language Journal & SSCI journal & 8 & 2.24 \\
\hline Applied Linguistics & SSCI journal & 7 & 1.96 \\
\hline Deutsch: Lehren und Lernen & practitioner / non-SSCI journal & 6 & 1.68 \\
\hline British Educational Research Journal & SSCI journal & 6 & 1.68 \\
\hline
\end{tabular}

Total \% of all mentions 64.15

Note. ${ }^{a}$ When given by respondents, the label "ALL publications" could include The Language Learning Journal, the language specific journals of ALL (e.g., Francophonie, Vida Hispánica, Deutsch: Lehren und Lernen), the magazine Languages Today, and newsletters.

$<C>$ Other Sources. Participants were asked in the full survey: How many reports about research from other sources have you read? Options were: On the internet; From a policy source (e.g., government document); From a circular sent to schools; Other (please specify). Figure 2 shows $67 \%$ of SB and $89 \%$ of NSB reported having read four or more research reports from the internet, with high proportions of respondents reporting eight or more. We did not collect more details but given the publications reported (Table 4), these internet sources were highly unlikely to be SSCI journals as almost none are entirely open 
access (cost free for author and reader) (just two in Table 8) and schools do not hold subscriptions. (See Appendix F for data about the two other sources: policy documents and information sent directly to schools).

\section{FIGURE 2}

Total Number of Reports About Research Read From Internet Sources (Full Survey)

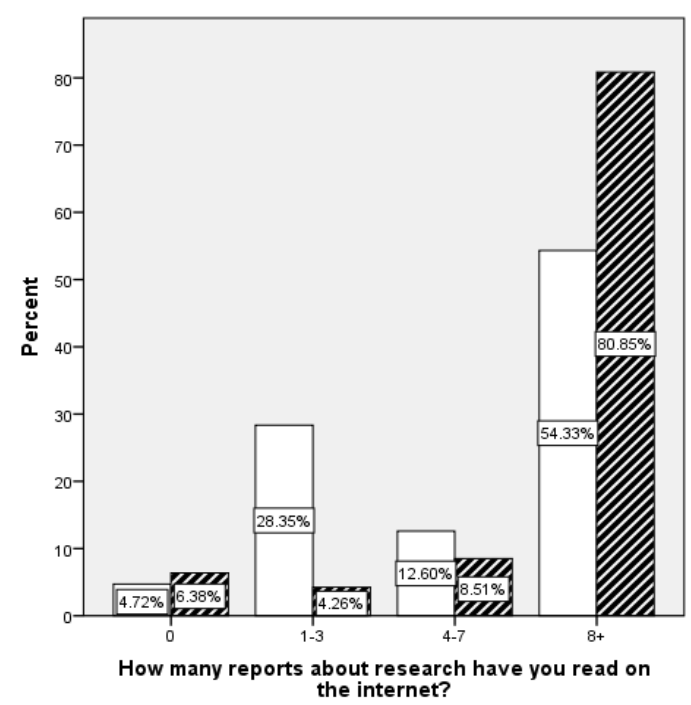

For "Other" sources, five respondents mentioned books: two SB and two NSB reported having read a total of 8 or more. Books were never mentioned in the other open fields provided in either survey.

$<C>$ Factors Preventing Engagement with Research. The second set of survey items elicited the reported impact of a number of factors (e.g., perceptions, funding, time, access) on engagement with research. Figure 3 presents the mean rating (between 0-100) given by SB and NSB for the full and short surveys. 
FIGURE 3

Mean(SD) Ratings for Factors Preventing Engagement with Research
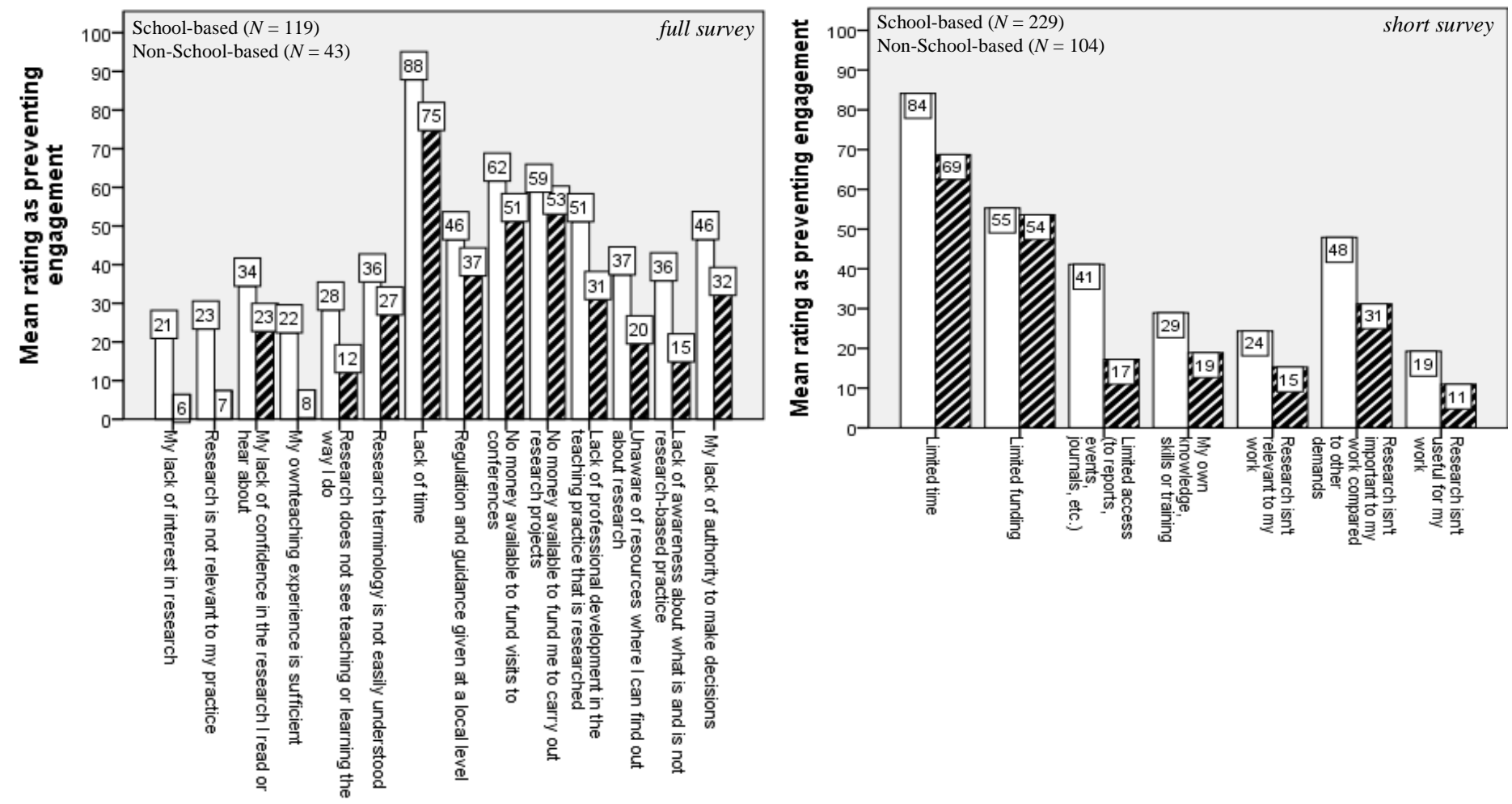

For the full survey data, the PCA reduced the 14 items to four separate components (Table 5).

Component 1 consisted of the items related to negative perceptions/attitudes to research (henceforth 'Negative perceptions of research'). Components 2 (funding) and 3 (time and local regulation), each with two items, both related to what we deemed to be 'Practical constraints'. The fourth component was identified as relating to 'Access and understanding'.

The 7 items in the short survey reduced to two separate components that were interpreted as consistent with Components 'Negative perceptions of research' and 'Practical constraints' also identified by the full survey analysis (Table 5). The PCAs accounted for $65.96 \%$ and $56.97 \%$ of the total variance in the data from the full and short surveys respectively, meeting Field's (2009) recommended minimum of 55-65\%. 
In sum, two components emerged from both datasets (Negative perceptions of research and Practical constraints) and one from additional items contained in the full survey (Access and understanding).

<INSERT TABLE 5 ABOUT HERE>

\section{TABLE 5}

Factor Loadings of Survey Items onto PCA Components and Proposed Reduced Variables

\begin{tabular}{|c|c|c|c|c|c|c|}
\hline & \multicolumn{2}{|c|}{$\begin{array}{c}\text { Reduced Variable 1: } \\
\text { Negative Perceptions of Research }\end{array}$} & \multicolumn{2}{|c|}{$\begin{array}{l}\text { Reduced Variable 2: } \\
\text { Practical Constraints }\end{array}$} & \multicolumn{2}{|c|}{$\begin{array}{c}\text { Reduced Variable 3: } \\
\text { Access and Understanding }\end{array}$} \\
\hline & $\begin{array}{c}\text { Component } 1 \\
(35.49 \% \text { variance })\end{array}$ & $\begin{array}{c}\text { Factor } \\
\text { Loading }\end{array}$ & $\begin{array}{c}\text { Component } 2 \\
\text { (13.75\% variance) }\end{array}$ & $\begin{array}{l}\text { Factor } \\
\text { Loading }\end{array}$ & $\begin{array}{c}\text { Component } 4 \\
(8.14 \% \text { variance })\end{array}$ & $\begin{array}{l}\text { Factor } \\
\text { Loading }\end{array}$ \\
\hline \multirow{7}{*}{$\begin{array}{l}\grave{0} \\
\grave{\Xi} \\
\bar{\Xi} \\
\end{array}$} & $\begin{array}{l}\text { My lack of interest in } \\
\text { research. }\end{array}$ & 0.754 & $\begin{array}{l}\text { No money available } \\
\text { to fund visits to } \\
\text { conferences. }\end{array}$ & 0.917 & \multirow{6}{*}{$\begin{array}{l}\text { Lack of professional } \\
\text { development in the } \\
\text { teaching practice } \\
\text { that is researched. } \\
\text { Unaware of } \\
\text { resources where I } \\
\text { can find out about } \\
\text { research. } \\
\text { Lack of awareness } \\
\text { about what is and is } \\
\text { not research-based } \\
\text { practice. } \\
\text { My lack of authority } \\
\text { to make decisions. }\end{array}$} & -0.542 \\
\hline & $\begin{array}{l}\text { Research is not } \\
\text { relevant to my practice. }\end{array}$ & 0.828 & $\begin{array}{l}\text { No money available } \\
\text { to fund me to carry } \\
\text { out research } \\
\text { projects. }\end{array}$ & 0.947 & & -0.817 \\
\hline & $\begin{array}{l}\text { Lack of confidence } \\
\text { (i.e. trust) in the } \\
\text { research I read or hear } \\
\text { about. }\end{array}$ & 0.575 & & & & -0.833 \\
\hline & $\begin{array}{l}\text { My own teaching } \\
\text { experience is } \\
\text { sufficient. }\end{array}$ & 0.695 & $\begin{array}{c}\text { Component } 3 \\
(8.59 \% \text { variance })\end{array}$ & $\begin{array}{l}\text { Factor } \\
\text { Loading }\end{array}$ & & -0.450 \\
\hline & $\begin{array}{l}\text { Research does not see } \\
\text { learning or teaching } \\
\text { the way I do. }\end{array}$ & 0.833 & Lack of time. & 0.8 & & \\
\hline & $\begin{array}{l}\text { Research terminology } \\
\text { is not easily } \\
\text { understood. }\end{array}$ & 0.517 & $\begin{array}{c}\text { Regulation and } \\
\text { guidance given at a } \\
\text { local level. }\end{array}$ & 0.767 & & \\
\hline & $\begin{array}{c}\text { Component } 1 \\
\text { (39.85\% variance) }\end{array}$ & $\begin{array}{c}\text { Factor } \\
\text { Loading }\end{array}$ & $\begin{array}{c}\text { Component } 2 \\
(17.12 \% \text { variance })\end{array}$ & $\begin{array}{c}\text { Factor } \\
\text { Loading }\end{array}$ & & \\
\hline \multirow{4}{*}{ 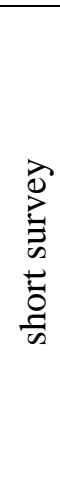 } & $\begin{array}{l}\text { Research isn't relevant } \\
\text { to my work }\end{array}$ & 0.896 & Limited time & 0.592 & & \\
\hline & $\begin{array}{l}\text { Research isn't } \\
\text { important to my work } \\
\text { compared to other } \\
\text { demands }\end{array}$ & 0.771 & Limited funding & 0.726 & & \\
\hline & $\begin{array}{l}\text { Research isn't useful } \\
\text { for my work }\end{array}$ & 0.889 & $\begin{array}{l}\text { Limited access (to } \\
\text { reports, events, } \\
\text { journals) }\end{array}$ & 0.713 & & \\
\hline & & & $\begin{array}{l}\text { My own knowledge, } \\
\text { skills or training }\end{array}$ & 0.426 & & \\
\hline
\end{tabular}


To investigate the relative impact of these barriers, an overall percentage rating per component was calculated for each respondent, separately for each survey (see Figure 4). For both surveys, SB and NSB respondents reported that Practical constraints were the greatest hindrance to research engagement, followed by 'Access and understanding', with 'Negative perceptions of research' a relatively small hindrance. Differences in mean ratings were statistical overall $(F(2,322)=217.798, p=0.001)$ and between each pair of components according to the Bonferroni pairwise comparisons: Negative perceptions of research < Practical constraints ( $p=0.001, d=1.82$, a large within-subject effect); Practical constraints $>$ Access and understanding ( $p=0.001, d=1.07$, a medium-large effect); Negative perceptions of research $<$ Access and understanding ( $p=0.001, d=0.64$, a small effect). Thus although in the PCA the largest amount of the variance was accounted for by the component Negative perceptions about research - as respondents showed more varied opinions about these items - it was the other barriers that respondents felt were more of a hindrance to research engagement.

A MANOVA revealed a difference between SB and NSB ratings for each variable for both the full $(F(3,158)=8.725, p=.001$, Wilks's $\Lambda=.858)$, and short surveys $(F(2,330)=$ $17.898, p=.001$, Wilks's $\Lambda=.902$,). Across all components on both surveys, SB ratings were higher than NSB ratings, with small to medium effect sizes: Full survey: Perceptions of research $(\mathrm{F}(1,160)=16.775, p=.001, d=0.80) ;$ Practical constraints $(\mathrm{F}(1,160)=6.752, p$ $=.001, d=0.47) ;$ Access and understanding $(\mathrm{F}(1,160)=21.483, p=.001, d=0.85)$. Short survey: Perceptions of research $(\mathrm{F}(1,331)=15.058, p=.001, d=0.46)$; Practical constraints $(\mathrm{F}(1,331)=31.494, p=.001, d=0.68)$. 


\section{FIGURE 4}

Mean(SD) Percentage Rating per Component
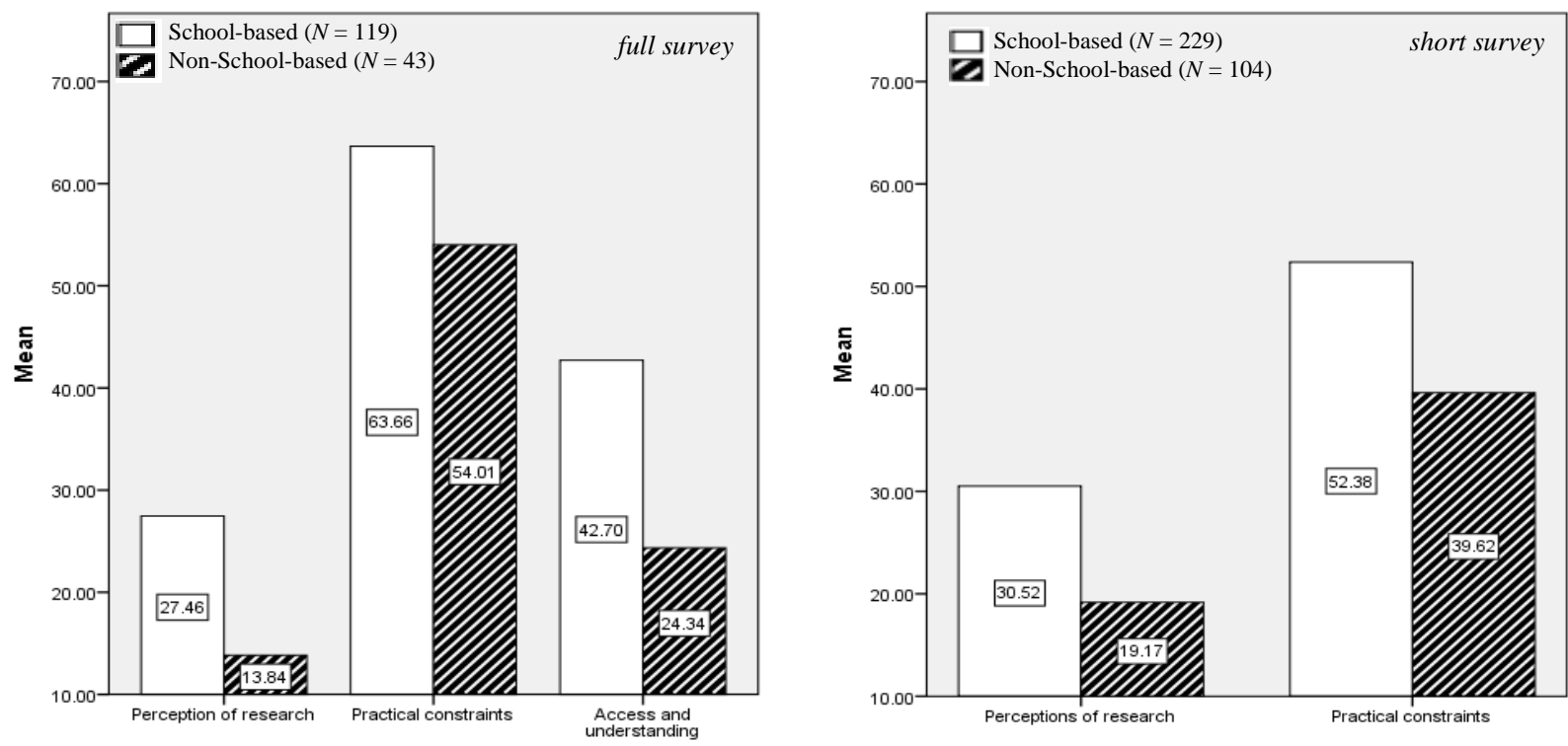

Consistent with findings about perception of research from both surveys were the responses to the question "In your opinion, is the research that you are aware of relevant to everyday classroom practice?", shown in Figure 5. Reassuringly for the research community, only $5.0 \%$ of SB and zero NSB perceived research as not at all relevant. Perceived relevance of research to practice varied with Position $\left(\chi^{2}(2)=16.076, p=.001\right)$.

\section{FIGURE 5}

Perceived Relevance of Research to Classroom Practice (Full Survey)

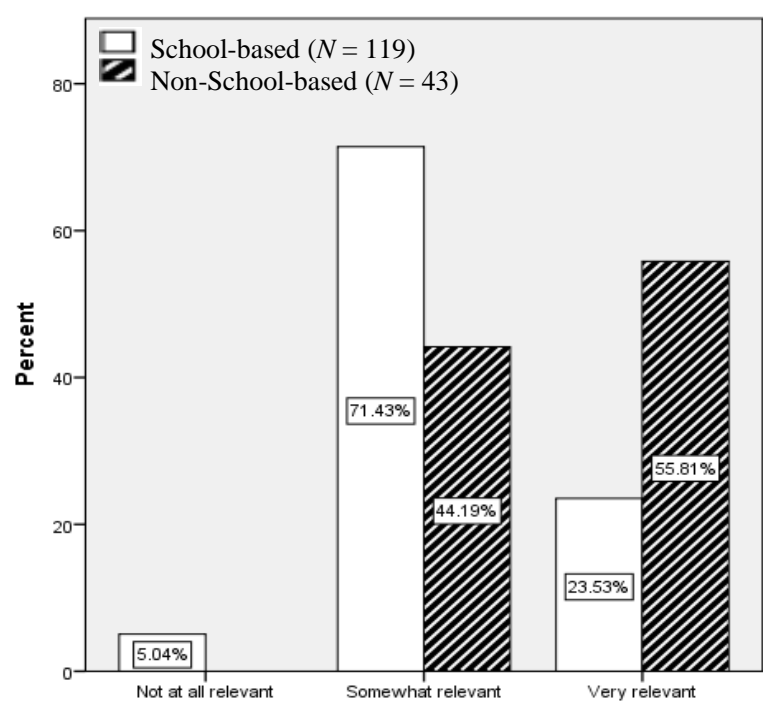


$<B>$ Summary of Part 1.

We found exposure to written research was largely via professional association magazines /newsletters /reports and non-SSCI journals, with very little via SSCI publications or research conferences. Although perhaps unsurprising, to our knowledge these data provide the first evidence about the scale and nature of the interface with research for non-English FL educators.

Also as anticipated, across all questions in both surveys, NSB reported engaging in statistically significantly more 'consumption of research' than SB, with large to very large effect sizes. This provides much needed data that validates concerns that moving teacher education away from university-based programmes will weaken relations between research and practice. However, we also note that the reading of research, both original reports and through 'mentions' in other publications, was fairly low even among NSB, with $27.1 \%$ reporting never having read an article about research. This provides data for further debate about realistic roles, capacities and needs of teacher educators and professional development providers.

Consistent with findings from ESL/EFL practitioners (e.g., Borg, 2013), practical constraints, particularly a lack of time, were key barriers preventing engagement with research. Whilst negative perceptions about the potential relevance or usefulness of research were not a key factor, difficulties in physically accessing and understanding research reports were.

$<$ A >PART 2: REFERENCES TO ACADEMIC JOURNALS FROM PRACTITIONER JOURNALS IN THREE ANGLOPHONE CONTEXTS

Although we found little evidence of direct exposure to the SSCI ISLA journals, it is possible that practitioners are indirectly exposed to such research via citations in practitioner- 
oriented publications. That is, research from SSCI journals could be discussed in material that teachers have access to, and so is available in a 'digested', 'cascaded,' or 'filtered' form. For example, do articles in The Language Learning Journal, the source most commonly mentioned by our respondents, cite the research findings reported in SSCI journals? To explore this question we carried out a 'reference mapping': a systematic review of the references (i.e. content of bibliographies) in a selection of publications to which practitioners are likely to have potential access.

$<$ B Methods

$<C>$ Selection of Professional Publications. We selected journals available to FL practitioners in three Anglophone contexts (Australia, UK, United States) that were published by professional associations and not on the SSCI. Authors of articles in these journals frequently include university faculty (including internationally recognised researchers), university-based teacher educators (with varying research remits within their professional identities), as well as practising teachers in primary through to university sectors (some of whom may have completed an $\mathrm{MA}$ or $\mathrm{PhD}$ ). The studies reported are usually related to the national context and situated, to varying extents, within an international body of research. From the UK, we chose The Language Learning Journal (2011, 39(1)-2015, 43(3)) and the three ALL language specific journals (Francophonie; Deutsch Lehren und Lernen; Vida Hispánica) (all articles available online; 2012-2015). These are available through membership to the ALL, and were the publications that our survey respondents mentioned most frequently (46\% of all mentions). From Australia, we chose Babel, the journal of the Australian Federation of Modern Language Teachers Association (2010, 44(2)-2014, 50(1)), available with association membership. From the United States, we examined NECTFL 
Review, the journal of the Northeast Conference on the Teaching of Foreign Languages (2011, \#67-2016, \#77), available open access online. ${ }^{13}$

Note that although our UK practitioner publications were the 'most' read by our survey respondents, $51.37 \%$ of respondents did not mention these publications at all. Thus, it is important to bear in mind the likely low overall exposure.

$<C>$ Selection of Academic Journals. We identified the SSCI journals that explicitly endeavour to publish research relevant to instructed language learning. To do this, we examined the Aims and Scope of each of the 179 journals in the SSCI Linguistics category to determine whether they self-identify as publishing research relevant to foreign or second language pedagogy, broadly defined. Journals were selected if their Aims included the following terms: (a) (foreign OR second) language (learning OR acquisition) AND (b) (pedagogy OR practice OR instruction OR teaching OR school OR applied linguistics). Criteria 1 restricted the type of language learning (excluding journals that addressed only bilingualism or first language learning) and criteria 2 ensured instructed contexts were within the journals' scope. 29 journals (16.2\%) met these criteria (see Table 8). For convenience, these are henceforth referred to as 'ISLA journals', though clearly these journals are not exclusively dedicated to instructed SLA research (see Discussion).

$<C>$ Reference Mapping. The reference lists (bibliographies) in all articles from the last five years of the seven practitioner publications were analysed to determine the proportions of different types of references. A unique reference was defined as one set of bibliographic information for a source that was cited in the text of an article. The references were almost always given in a reference section at the end of each article, though very occasionally in a foot- or endnote. Each reference was coded as either: 'ISLA journal', with sub-labels for each journal; 'other journal article'; 'book/book chapter'; 'textbook' (i.e., pedagogical material); 'professional magazine/newsletter'; 'policy document'; 'other'. If a 
journal or book was referenced more than three times in any one professional journal, this was documented to check whether specific journals or books were being referenced beyond our 29 ISLA journals.

$<B>$ Results

Table 6 details our corpus of references.

TABLE 6

Corpus of Professional Journal Articles

\begin{tabular}{cccccc} 
& Total & LLJ & $\begin{array}{c}\text { ALL Lang } \\
\text { (3 publications) }\end{array}$ & Babel & $\begin{array}{c}\text { NECTFL } \\
\text { Review }\end{array}$ \\
\hline Total articles & 284 & 116 & 71 & 62 & 35 \\
\hline Total references & 8516 & 4780 & 557 & 1704 & 1475 \\
\hline $\begin{array}{c}\text { Mean references per } \\
\text { article }(S D)\end{array}$ & 29.99 & 41.21 & 7.85 & 27.48 & 42.14 \\
& $(21.40)$ & $(18.35)$ & $(8.03)$ & $(13.81)$ & $(24.11)$ \\
\hline
\end{tabular}

Table 7 shows the proportions of references of each type in each of our professional journals.

The overall mean proportion of references to ISLA journals was $12.43 \%$, with substantial variation both within and across the publications. In just over one third of the professional journals articles $(37 \%, k=105)$, the proportion of references to ISLA journals was zero. $3 \%$ $(k=8)$ of the articles contained $50 \%$ or more ISLA references. The means ranged from $2.79 \%$ in the 'ALL language specific journals' to $25.08 \%$ in the NECTFL Review. 
TABLE 7

Proportion of References by Type

Mean \% References Per Article (SD)

\begin{tabular}{|c|c|c|c|c|c|c|}
\hline & & Total & $L L J$ & ALL Lang & Babel & $\begin{array}{l}\text { NECTFL } \\
\text { Review }\end{array}$ \\
\hline \multirow{3}{*}{ Journal articles } & ISLA & $12.43(15.14)$ & $17.04(15.60)$ & $2.79(8.78)$ & $7.71(9.92)$ & $25.08(16.69)$ \\
\hline & Other & $20.66(16.02)$ & $24.70(14.58)$ & $8.32(15.69)$ & $24.19(14.25)$ & $26.06(10.98)$ \\
\hline & Total & $33.07(23.16)$ & $41.70(18.72)$ & $11.1(19.64)$ & $31.87(17.23)$ & $51.12(18.81)$ \\
\hline \multicolumn{2}{|c|}{ Books /Book chapters } & $35.85(24.74)$ & $42.26(19.14)$ & $30.72(36.56)$ & $34.08(17.47)$ & $28.17(17.11)$ \\
\hline \multicolumn{2}{|c|}{ Textbooks } & $1.88(7.37)$ & $0.78(2.46)$ & $3.98(13.43)$ & $1.25(3.23)$ & $2.36(5.17)$ \\
\hline \multicolumn{2}{|c|}{$\begin{array}{r}\text { Professional magazines / } \\
\text { Newsletters }\end{array}$} & $0.32(1.30)$ & $0.37(1.17)$ & $0.28(1.69)$ & $0.37(1.33)$ & $0.09(0.54)$ \\
\hline \multicolumn{2}{|c|}{ Policy documents } & $8.61(14.00)$ & $6.82(11.14)$ & $5.90(17.58)$ & $15.13(12.94)$ & 8.47 (13.04) \\
\hline & Other & $14.97(22.40)$ & $8.07(10.46)$ & $26.88(36.50)$ & $17.14(16.77)$ & $9.80(7.82)$ \\
\hline
\end{tabular}

Table 8 details the mean raw number of references per article to each of our 29 ISLA journals, with some variation but almost all being far less than 1 , indicating that on average these journals are referenced less than once per article. For example, 0.1 indicates that a mean of 1 in every 10 articles in the professional journal would contain a reference to that ISLA journal. The overall mean of the mean across all our professional journals $(0.17$, SD 0.19$)$ indicates that on average a reference to any one of the ISLA journals occurs approximately one in every six articles. 


\section{TABLE 8}

Mean (SD) Number of References per Article to ISLA Journals

Mean Number of References per Article in Professional Journal (SD)

\begin{tabular}{|c|c|c|c|c|c|}
\hline ISLA Journals $^{14}$ & Total & $L L J$ & ALL Lang & Babel & $\begin{array}{l}\text { NECTFL } \\
\text { Review }\end{array}$ \\
\hline Applied Linguistics & $0.42(0.97)$ & $0.78(1.32)$ & $0.03(0.17)$ & $0.23(0.58)$ & $0.31(058)$ \\
\hline Applied Psycholinguistics & $0.04(0.30)$ & $0.09(0.45)$ & 0 & $0.02(0.13)$ & $0.03(0.17)$ \\
\hline Canadian Modern Language Review & $0.18(0.51)$ & $0.34(0.70)$ & $0.01(0.12)$ & $0.05(0.22)$ & $0.17(0.45)$ \\
\hline English for Specific Purposes & $0.03(0.20)$ & $0.06(0.30)$ & $0.00(0.00)$ & 0 & $0.03(0.17)$ \\
\hline Foreign Language Annals & $0.67(2.20)$ & $0.28(0.90)$ & $0.03(0.17)$ & $0.11(0.37)$ & $4.20(4.75)$ \\
\hline Intercultural Pragmatics & $0.01(0.08)$ & $0.01(0.09)$ & 0 & $0.02(0.13)$ & 0 \\
\hline $\begin{array}{l}\text { Language and Intercultural } \\
\text { Communication }\end{array}$ & $0.05(0.60)$ & $0.03(0.16)$ & 0 & 0 & $0.29(1.69)$ \\
\hline Language Awareness & $0.09(0.52)$ & $0.14(0.72)$ & $0.01(0.12)$ & $0.03(0.18)$ & $0.17(0.62)$ \\
\hline Language Learning & $0.32(0.97)$ & $0.53(1.32)$ & $0.07(0.35)$ & $0.16(0.41)$ & $0.40(1.04)$ \\
\hline $\begin{array}{r}\text { *Language Learning and } \\
\text { Technology }\end{array}$ & $0.19(1.03)$ & $0.28(1.21)$ & $0.01(0.12)$ & $0.02(0.13)$ & $0.51(1.90)$ \\
\hline Language Teaching & $0.19(0.57)$ & $0.28(0.59)$ & 0 & $0.16(0.41)$ & $0.31(1.05)$ \\
\hline The Modern Language Journal & $0.74(1.60)$ & $0.67(1.24)$ & $0.06(0.29)$ & $0.47(0.92)$ & $2.86(2.97)$ \\
\hline *Porta Linguarum & $0.01(0.12)$ & $0.03(0.16)$ & $0.01(0.12)$ & 0 & 0 \\
\hline Pragmatics and Society & 0 & $0(0)$ & 0 & 0 & 0 \\
\hline ReCALL & $0.09(0.43)$ & $0.16(0.63)$ & $0.01(0.12)$ & $0.05(0.22)$ & $0.09(0.28)$ \\
\hline $\begin{array}{r}\text { RELA/Spanish Journal of Applied } \\
\text { Lings }\end{array}$ & $0.01(0.08)$ & $0.01(0.09)$ & $0.01(0.12)$ & 0 & 0 \\
\hline Acquisition & $0.25(1.15)$ & $0.52(1.68)$ & $0.03(0.24)$ & $0.03(0.18)$ & $0.17(0.86)$ \\
\hline System & $0.31(0.99)$ & $0.67(1.44)$ & 0 & $0.02(0.13)$ & $0.26(0.61)$ \\
\hline TESOL Quarterly & $0.42(0.91)$ & $0.71(1.14)$ & $0.01(0.12)$ & $0.27(0.73)$ & $0.51(0.92)$ \\
\hline
\end{tabular}


Vial-Vigo Internat. Journal of Applied Linguistics

$$
0.01(0.08) \quad 0.02(0.13)
$$

0

0

0

Computer Assisted Language

$$
0.08(0.41) \quad 0.16(0.56) \quad 0 \quad 0.11(0.53)
$$

Learning

Annual Review of Applied

\section{Linguistics}

$$
0.07(0.25)
$$

$0.12(0.33)$

$0.01(0.12)$

$0.03(0.18)$

$0.06(0.24)$

Applied Linguistics Review

$$
0.00(0.06) \quad 0.01(0.09)
$$

0

0

0

ELT Journal

$$
0.25(0.75)
$$

$0.46(1.03)$

$0.01(0.12)$

$0.16(0.55)$

$0.23(0.49)$

IRAL in Language Teaching

$$
0.05(0.25)
$$

$0.09(0.34)$

0

$0.05(0.22)$

$0.06(0.24)$

Journal of French Language Studies

$0.01(0.15)$

$0.03(0.23)$

0

0

0

Language, Culture and Curriculum

$0.09(0.59)$

$0.10(0.33)$

$0.01(0.12)$

0

$0.34(1.53)$

Language Teaching Research

$0.24(0.76)$

$0.42(1.00)$

0

$0.16(0.71)$

$0.23(0.49)$

Language Testing

$0.07(0.46)$

$0.14(0.66)$

0

$0.05(0.28)$

$0.06(0.34)$

$\begin{array}{llllll}\text { Overall mean } & 0.17(0.19) & 0.25(0.24) & 0.01(0.02) & 0.07(0.11) & 0.39(0.90)\end{array}$

* Journals are completely open access, entirely free to authors and readers.

NECTFL Review contained the highest proportion of references to ISLA journals (mean 25.08\%, SD 16.69, per article). About one third of these (mean 32.42\%, SD 25.27) were to Foreign Language Annals (FLA) and a quarter (28.03\%, SD 28.35) to The Modern Language Journal $(M L J)$. To benchmark against our other professional publications: the overall mean proportion of their ISLA references to $F L A$ was $2.78 \%$ and to the $M L J$ was 8.15\% (Appendix G). Therefore, NECTFL Review's overall higher proportion of ISLA references was largely $(60.45 \%)$ due to references to two journals (linked to national associations, American Council of Teachers of Foreign Languages and National Federation of Modern Language Teachers Associations). Excluding these, the proportion of references to ISLA journals was $9.17 \%$, closer to the other practitioner journals. 
It is of course possible that some ISLA journals themselves provide a link between research and practitioners. For example, FLA is the official journal of a professional teaching association but did not meet our criteria for a practitioner publication because it is in the SSCI. To probe a little deeper into potential 'cascading' effects, we examined the references within FLA itself.

Between 2011-2015, FLA published 190 articles with 8,713 references, a mean of $45.86(S D=19.43)$ references per article, shown in Table 9 by type.

\section{TABLE 9}

Reference Types in FLA

Mean \% of Total References

per Article $M(S D)$

\begin{tabular}{rrc}
\hline \multirow{2}{*}{$\begin{array}{l}\text { Journal } \\
\text { articles }\end{array}$} & OSLA & $26.06(15.30)$ \\
\cline { 2 - 3 } & Other & $25.76(14.53)$ \\
\cline { 2 - 3 } & Bll & $51.82(17.00)$ \\
\hline Tooks / Book chapters & $34.43(15.67)$ \\
\hline Trofessional magazines / & $0.66(1.57)$ \\
Newsletters & $0.31(0.94)$ \\
\hline Policy documents & $4.14(7.14)$ \\
\hline Other & $8.23(8.02)$ \\
\hline
\end{tabular}

Closely reflecting the pattern of references in NECTFL Review, a mean of $26.06 \%$ (SD = 15.30) were to the ISLA set. Of these, over a quarter were to $F L A(27.69 \%, S D=26.43)$ and a fifth to $M L J(20.85 \%, S D=20.22)$, leaving approximately $13 \%$ to other ISLA journals, closer to the overall mean. This again demonstrates an influence of research reported in the $M L J$ and FLA, but leaves little evidence of a strong flow of research findings from the other 27 ISLA journals. 


\section{$<$ A $>$ DISCUSSION}

Addressing Aim 1, our UK FL practitioners reported a small amount of exposure to material that mentioned research, and very low amounts of reading first hand reports in academic ISLA journals. Approximately a third of SB practitioners reported reading or hearing zero to five times material that mentioned research over the last $12-$ month period, and $70 \%$ reported reading or hearing fewer than two original research reports. SB respondents reported a mean total of 9 publications (of all types) ever read compared to 26 for NSB, with the vast majority of these being practitioner publications and magazines/newsletters (84\%). Our data should be interpreted in the light of a probable selfselection bias in our sample - connection to the networks through which we administered our survey and willingness to complete a "Research and MFL teaching" survey may correlate positively with exposure to research. Despite this probable skew, we found severely limited amounts of exposure to research.

Our data suggested a role for the national professional subject association, with a third of publications and events mentioned being affiliated with ALL, and other sources being relatively ad hoc and smaller in number.

The data also suggested greater exposure to research for NSB practitioners, a strong indication that shifts to school-based teacher education would likely erode existing interfaces between research and practice without sustained infrastructure or action to mitigate against this, validating concerns raised by Lawes (2003) and Macrory (2015).

Addressing Aim 2, reported barriers to research engagement bunched into three types: practical constraints, limited physical and conceptual access, and negative perceptions of research. Practical constraints (e.g., time, funding) were the biggest inhibitory factor, followed by issues related to physical and conceptual access. This corroborates data from 
EFL teachers (e.g. Borg, 2007; Ellis, 2010) who identified practical difficulties of locating written research (e.g., knowing where to look, journal subscriptions, time constraints) and conceptual difficulties of evaluating the applicability of research to the local context (Williams \& Coles, 2007). Our respondents made suggestions about addressing these issues in an open response item in our survey (which we are unable to present in detail due to space constraints): 34 (40\%) of the 86 offering a response suggested that distilling research findings into non-technical summaries which are disseminated via practitioner outlets would facilitate access. 19 other respondents made suggestions such as provide easier access to findings, disseminate research via practitioner outlets, and provide web links to research findings.

The third type of barrier related to negative perceptions of research, but was a less important hindrance. Arguably, perceptions about relevance or usefulness could be invalidated by respondents' limited experience of research in the first place. Nevertheless, the survey item explicitly directed respondents to consider research that they had read or heard. In any case, it is perhaps reassuring that at least a priori negative prejudices are unlikely to be a significant hindrance. To us, this suggested a more positive picture of the potential of the research-practice interface than some previous studies (Kiely, 2014; Montgomery \& Smith, 2015, Shkedi, 1998), indicating that increased effort in our communication infrastructure would, therefore, be worthwhile.

Addressing Aim 3, we found references to research in SSCI journals that aim to publish some pedagogically relevant research constituted about $12 \%$ of the bibliographies in professional journals. Although we have no benchmark against which to evaluate this (there is no 'optimum'), we consider this to be a surprisingly and worryingly low proportion. It is an indication that a considerable amount of tax-funded, often high quality research is far from achieving its potential exposure for practitioners to then evaluate its relevance to their own professional lives. However, there was considerable variability both within and across 
professional journals. In line with our UK survey data, we found evidence for some influence of national professional associations (and/or, perhaps, of the effort associated with the history and origins of their journals): in the US, references in The NECTFL Review to two journals (the $M L J$ and $F L A$, both associated with professional associations) increased the proportion of references to SSCI ISLA journals from $10.32 \%$ to $25.08 \%$, a pattern closely mirrored by references within FLA itself. However, we note that the Language Educator, the professional magazine of the American Council on the Teaching of Foreign Languages (ACTFL, the largest organisation in the USA dedicated to foreign language teaching), did not use sufficient references to research publications to be included in our review.

One potential explanation for the low proportion of references to SSCI ISLA journals could be the oft discussed 'lack of connection with the classroom' (Byrnes, 2016, pp. 7-8). But several arguments counter this as a complete explanation for poor flow of published research. First is the explicit intention of journals and researchers to publish research relevant to practice. Second, although ISLA research cannot provide directly relevant 'technical solutions for effectiveness', there is general consensus that it has relevance in terms of enriching reflectiveness and pedagogical decision-making. Third, our UK survey respondents did not express severe concerns about a lack of relevance or usefulness. Finally, we argue that there is a great deal of potentially relevant research, as found by two recent survey articles. First, 97 intact classroom studies were found by Collins and Muñoz (2016) in just one of our 29 journals - the $M L J$ - in the last 14 years. Second, Rose \& McKinley (2016), surveying only one year (2015) of just 10 self-identified applied linguistics journals, found that language-pedagogy-related studies constituted 32 per cent of articles (approximately 108/336). A further illustration of this point is as follows: The overall mean number of references to, for example, the SSCI journal Language Teaching Research was 0.24 per article in our professional publications (Table 8). If this was a reflection of the amount of 
relevance, this would suggest that only one in every four articles in our corpus of professional publications would find relevant research in the publishing history of Language Teaching Research, that is, approximately 456 articles (1997-2017); we believe that is highly unlikely (see also Barkhuizen, 2013), though we acknowledge this is an empirical question.

Our findings, from both Parts of the study, remind researchers not to 'drop the ball' of communicating our research. The current "methodological turn" (Byrnes, 2013, p. 825) in our field has the long term ambition of increasing relevance and usefulness by improving the insights that research can offer practice (e.g., synthesising findings, replicating, broadening our participant demographics, strengthening study designs, and improving methodological transparency, instrument reliability and statistical reporting, e.g. Marsden, Mackey, \& Plonsky, 2016; Marsden, Morgan-Short, Thompson \& Abugaber, under review; Marsden \& Torgerson, 2012; Ortega, 2005; Plonsky \& Derrick, 2016; Plonsky \& Oswald 2014). However, systematic, sustained effort in the research-practice interface is needed to make this effort worthwhile perhaps, as relevance and usefulness were in fact much less of a concern than time and physical and conceptual access, for our respondents at least.

Our study focused on one step: exposure to research. Another issue relates to research literacy and empowering practitioners to evaluate relevance to context (Borg, 2010; Cordingley, 2004; Ellis, 2010; Hammersley, 2003; Hatch, 1978; Larsen-Freeman, 2009, 2015; McMillan \& Wergin, 2010; Ortega, 2012; Pachler, 2003). We emphatically do not use our data to recommend that school-based practitioners should read articles in SSCI journals. Nor are we arguing for a radical change in the nature or aims of research in SSCI ISLA journals (we acknowledge for example that theory-driven questions can require isolation from 'real world problems' (Brumfit, 1995)). We propose, rather, a small addition to the ISLA field's publication practices that may help increase physical and conceptual access to a 
body of research that has been conducted and reviewed with a certain degree of rigour (if we perceive citation indices as one marker of quality).

In sum, the action that we now propose was informed by each of the following key findings: (a) the limited practitioner exposure to peer reviewed published research, (b) the barriers caused by lack of time and physical and conceptual accessibility, (c) the relatively positive perceptions about the relevance and usefulness of research, (d) a potential role of subject associations and affiliated publications, (e) the stated aims of 29 SSCI journals, and (f) the low proportion of SSCI ISLA research referred to in professional journals.

\section{<A>A CALL FOR ACTION: JOURNAL-INITIATED LAY SUMMARIES}

SSCI journals who publish pedagogically relevant research, however broadly defined, could encourage, or ideally request, their authors, where appropriate, to reframe their academic publications into summary formats that are both physically and conceptually accessible to practitioners. Open access distribution of these brief (one page) "lay summaries" could be via international research and professional umbrella associations, such as AILA and FIPLV, and/or posted on one sustained, searchable web resource. All interested organisations, such as national teacher associations, could link to this one platform. Materials that could be useful to practitioners could be made available via, for example, the IRIS repository (www.iris-database.org). Open access distribution would likely occur via social media (recall that high proportions of our respondents reported accessing material via the internet, whilst only two of our 29 ISLA journals are open access). This could be a costeffective mechanism for reducing barriers relating to time, funding, and both physical and conceptual access, and for increasing the likelihood of exposure to internationally peerreviewed research. 
Our proposal may also help to address other issues identified at the start of this article. First, a journal-led approach may be necessary to address the problem that researchers are rarely incentivised to do this from other quarters. Note that the 'impact agendas' in Australia, the UK and the USA do not incentivise isolated acts such as publishing in a professional outlet. In the UK, for example, to qualify as 'impact' concrete evidence of observable effects on non-academic users is required. Further, our data from the UK and Australia, contexts where the impact agenda is more embedded, did not suggest a better flow of academic publications to professional interfaces compared to our data from the USA, a context with a less explicitly developed impact agenda.

Second, the discipline specific (i.e., language education) nature of our proposal may be necessary given that general education infrastructures and initiatives have tended to be short-lived and seem to be more sensitive to political climates than academic journals, many of which have enjoyed relative longevity.

Mechanisms related to the one we are proposing are in place in some FL contexts. For example, the Paul Pimsleur (ACTFL-NFMLTA) and Birkmaier (NFMLTA) Awards recognise FL education research (though to our knowledge neither require the recipients to disseminate their research to practitioners). The Language Educator's (ACTFL's magazine) produces 5-10 line summaries of FLA articles. As noted, however, in FLA approximately $13 \%$ of the references were to other SSCI ISLA journals (i.e. excluding $M L J$ and $F L A$ ), and so these summaries do not address the gaps we have identified with the wider body of international ISLA research. What we propose here would (a) cover more research, from more journals, (b) serve a more international audience, (c) incentivise researchers, and (d) provide more information about each study to help readers determine relevance more easily.

Establishing such an infrastructure would be in line with movements across the life sciences and psychology. There are now over 50 journals and societies that publish plain 
language summaries (eLife, 2017). But this will not be a trivial undertaking for our domain. It requires sensitive consideration of many matters affecting feasibility and ultimate usefulness, such as journal and professional association take-up, author/editorial responsibilities for the content and style of summaries, ownership of intellectual property and relations with publishing houses. For example, eLife has now published over 2,400 plain language digests (King, Pewsey \& Shailes, 2017), but the burden of work falls on a group of feature editors who write the summaries and then collaborate with the original authors for fine-tuning. Other examples include: Archives of Scientific Psychology's lay abstracts alongside their scientific abstracts; Perspectives in Medical Education (an open access journal) has short plain language "What this article adds" sections in each article; Proceedings of National Academy of Sciences have short 'Significance Statements' inserts in every article, which are then also released in a weekly open access publication; the American Educational Research Association annually publishes 4-5 line summaries of the twenty most downloaded education research articles, giving open access to each of these articles. To our mind, none of these provide a 'model' initiative, one key concern being the extent to which they take action to reach practitioner networks. Nevertheless, they offer food for thought.

Our proposal, which will hopefully springboard discussion in the field, is that journal Editors would encourage or require authors of relevant articles to create one page lay summaries and forward these to a central point (such as AILA, FIPLV, or one web resource), to which interested networks would link. Variation between journals would be expected: some may prefer Editorial oversight, others may prefer author autonomy; some may 'encourage' and some may 'require' author participation; some publishers may put the summaries open access on their websites to increase visibility; some may disseminate annually following Editorial board meetings, others more frequently; some may also engage directly with specific practitioner groups. But, we suggest, an overarching infrastructure, in 
terms of journal policy and one collection point, would bring essential momentum and economy of scale.

\section{$<$ A $>$ LIMITATIONS}

We have proposed that professional associations would be one effective conduit to increase the flow of written research, given the data from our surveys and reference mapping. Of course, other communication channels deserve systematic study to ascertain the extent to which they facilitate flow, such as books, social media, and face to face events. However, our school-based respondents reported hearing about research at events a mean of just three (median two) times over their career and very few mentioned reading books, suggesting these do not constitute a strong link to research. Nevertheless, $35 \%$ of references in our professional journals were to books, so it is possible that these references a) link to research reported in books (albeit often less rigorously peer-reviewed than some journals), and b) link indirectly to research reported in ISLA journals, that is, citations to books that in turn cite journals.

A related limitation of our study is that research may be communicated via, for example, CPD events, without overt recognition (or even awareness on the part of the CPD provider) that it is 'research', and so such potential interfaces are neglected by our investigation. Documenting such interfaces would require the investigators themselves to decide the extent to which the content of CPD events or material was informed by research; a valuable exercise. However, such implicit/covert communication of 'research' may not promote practitioners' awareness and criticality about what research can reasonably claim, or their own evaluation of its usefulness, validity or reliability.

Our review of professional journals probably over-estimates exposure to research via their citations therein. First, we did not quantify the repetition of references across articles, 
and although we did not find obvious examples of this, some amount of overlap was inevitable. Second, given the small amounts of reading reported in our UK survey, such indirect exposure is limited in its reach. Third, although these professional publications were the most frequently mentioned (almost half of all mentions) in our UK survey, further research is required to ascertain the extent to which U.S. and Australian practitioners read the publications we reviewed (but we suspect that findings would be similar to our UK data).

We recognise that not all research published in our ISLA journals is directly relevant to school FL teachers (e.g., we did not exclude 'English' or artificial languages) and that findings from research could rarely if ever be adopted wholesale in the classroom, as influence is indirect in that it raises awareness and informs innovation. However, adopting different views about research-practice relations would not, we think, greatly alter the implications of our findings. For example, whether we adopt a spiralling outwards/‘implications and applications’ view of research to pedagogy, or a case-study approach whereby socio-educational contextual factors are critical to interpretation of the study, or an awareness-raising/ reflective-practitioner model, or a co-constructed approach in which practitioner involvement is fully embedded throughout (Byrnes, 2016; Ellis \& Shintani, 2013; Long, 2000; Norris \& Manchón, 2012; Lantolf \& Poehner, 2015), our data indicate that these models would be similarly ill-served by the current flow of published academic research. Our point is more general: If any potential pedagogical relevance is claimed (by authors or editorial mission statements), the research could better find its way into practitioners' communities of practice, for evaluation by them. Looking even further ahead, it is possible that improvements in this dimension could, in turn, produce a kind of 'washback' that affects the aims, construction and design of ISLA research itself. 
Our study found little evidence of reading about research among school-based practitioners. Non-school based practitioners (university-based teacher educators and providers of professional development) reported significantly more, suggesting a role for university-based teacher education; however, low means and wide variation among these respondents raises concerns about the amount of scrutinised research that is currently made available to pre- and in-service teachers in the UK.

Our analyses of references provided an additionally sobering picture of the amount of research from SSCI journals that could be reaching practitioners through professional publications, with a mean $12.43 \%$ of references per article to a set of 29 international, academic, citation-indexed journals, - a somewhat discouraging landscape, given the likely low proportions of practitioners who read the professional publications in the first place.

These findings are important for researchers to bear in mind, as effort is steadily increased to enhance reliability, validity and generalisability. Within current infrastructure, the resulting higher quality, more rigorous research seems unlikely to reach its potential for access by practitioners.

We found that barriers to engagement with research tended to cluster into different types, several of which are within the research community's capacity to reduce. Although not in strong a position to reduce some (practical constraints such as resources), there is more potential for influence over others (physical and conceptual access, perceived relevance and usefulness, and time required to read about research). SSCI journals whose stated aims include pedagogical relevance are, arguably, ethically bound to facilitate FL educators' access to this research. Thus, we propose a formal and sustainable mechanism to help incentivise researchers to reduce the impact of such barriers, via open access summaries (i.e. cost free for authors and readers), distributed with the help of international and national subject associations. 
Our studies have provided some sobering evidence in support of "the troubling conclusion" that ISLA academic journals "no longer serve in a directly visible fashion the enormously complex set of issues pertaining to [school] language education" (Byrnes, 2016, p. 7, emphasis added). However, by providing data on practitioner exposure to research and by tracking a less 'visible' flow of research via referencing practices, we also provide evidence that there is not entirely "exclusionary relationship between research of the kind now privileged in journals like the $M L J$ and the reality of language teaching and learning" (Byrnes 2016 p. 8, emphasis added). We hope that our study engenders further investigations to make research-practice interfaces more visible, with a view to improving them. 


\section{$<$ ACKNOWLEDGEMENTS >}

We are grateful to: the British Association of Applied Linguistics for an 'Applying

Linguistics' award that supported the initial stage of this study; the Association for Language Learning in the UK for helping in survey distribution; our respondents in the UK; Rhonda Oliver, Rita Tognini and Matthew Absalom (in Australia) and Kevin McManus (in the USA) for facilitating access to practitioner publications; Philippa Bell, Heidi Byrnes, Laura Collins, Rosemary Erlam, Carrie Jackson, Roy Lyster, Luke Plonsky, Leila Ranta, and Paul Toth for indicating practitioner publications in the USA and Canada; and Charlotte Oliver and Chelsea Smith for helping to code the 17,299 references.

\section{NOTES}

${ }^{1}$ At the time of data extraction; subsequently, the Aims changed but the Instructions for Contributors states "the interface of acquisition and use with pedagogy are acceptable".

\section{${ }^{2}$ https://www.nationalcollege.org.uk/?q=node/641}

${ }^{3}$ Allocation of core research funding in the UK in 2014 depended $65 \%$ on academic outputs (largely journal articles) plus $15 \%$ on the 'research environment', compared to $20 \%$ on 'impact'.

${ }^{4}$ http://www.curee.co.uk/resources/publications_by_category and http://www.ntrp.org.uk/

${ }^{5}$ For example, the following are now discontinued, unavailable or archived: School Research News; Research Bites (90 second videos); a range of databases (e.g. Research for Teachers; Research Informed Practice Site; Teacher Training Research Bank; Practical Research for Education).

${ }^{6}$ https://pdcinmfl.com/

${ }^{7} \mathrm{CfBT}$ (now the Education Development Trust) is a UK education charity; ITET-Languages is an email forum for practitioners involved in Initial Teacher Education and Training, a sub-group of ALL. ${ }^{8}$ We give effect sizes for the paired comparisons, not the overall omnibus tests, as this is deemed more useful and giving both is not advised (Larson-Hall, 2016).

${ }^{9}$ A potential alternative choice of extraction model, Exploratory Factor Analysis, is likely to have given similar results (Plonsky \& Gonulal, 2015; Tarling, 2009), but was deemed less appropriate as 
our main aim was to reduce survey items, rather than explore underlying constructs, and EFA has encountered criticism (Tarling, 2009). Our choice of oblique rotation allows covariance between the factors, recommended when asking human participants about potentially related perceptions.

${ }^{10}$ For the full survey, the total possible rating for construct 1 (Perceptions of research) was 600 as it contained 6 items, each rated out of 100 . For the remaining two constructs it was 400, as each contained 4 items. For the short survey, the total possible rating for construct 1 (Perceptions of research, 3 items) was 300 and for construct 2 (Practical constraints, 4 items) was 400.

${ }^{11}$ To estimate the number of articles read for each publication type, the response options 2-3 and 4-7 were substituted with the middle values 2.5 or 5.5 respectively and the category $8+$ was substituted with the value 8 .

${ }^{12}$ LLJ was coded as such as it is not currently on the SSCI, though we emphasise that it is a peerreviewed journal that publishes work by and for an international audience.

${ }^{13}$ We also examined two issues of Languages Today (UK) and the Language Educator (USA), practitioner magazines. There were very few references in either publication. The Language Educator's section "FocusTopic" included a few articles, some of which had a small number of references, but none to our selection of academic journals (mainly to books, policy documents or other articles in the Language Educator). These magazines were not therefore included.

${ }^{14}$ The Journal of Second Language Writing (JSLW) did not meet our key word criteria in its published Aims, despite being an SSCI journal publishing ISLA research (Rose \& McKinley 2016 excluded $J S L W$ for similar reasons). However, $J S L W$ was referenced approximately 5 times in our corpus, so did not alter our patterns of findings. 


\section{REFERENCES}

American Association of Applied Linguistics. (2015) Promotion and Tenure Guidelines.

Accessed 4 April 2017 at http://www.aaal.org/?page=PT

Applied Linguistics. (2016), About the journal. Accessed 15 April 2016 at

http://www.oxfordjournals.org/our_journals/applij/about.html

Australian Research Council. (2016). Research impact principles and framework. Accessed 6 January 2017 at http://www.arc.gov.au/research-impact-principles-and-framework

Barkhuizen, G. (2013) Considering implications. Language Teaching Research, 17, 387 389.

Beauchamp, G., Clarke, L., Hulme, M., \& Murray, J. (2015) Teacher education in the United Kingdom post devolution: Convergences and divergences. Oxford Review of Education, 41, 154-170.

Belcher, D. (2007). A bridge too far? TESOL Quarterly, 41, 396-399.

Bell, D. (2015). School Direct is choking university teacher training courses. The Guardian. Accessed 14 April 2016 at http://www.theguardian.com/higher-educationnetwork/2015/jan/19/school-direct-is-choking-university-teacher-training-courses

Bell, M., Cordingley, P., Isham., C., \& Davis., R. (2010) Report of Professional Practitioner Use of Research Review: Practitioner engagement in and/or with research. Coventry: CUREE, GTCE, LSIS \& NTRP.

Bevan, R. M. (2004). Filtering, fragmenting, and fiddling? Teachers' life cycles, and phases in their engagement with research. Teacher Development, 8, 325-339.

Borg, S. (2003). Teacher cognition in language teaching: A review of research on what language teachers think, know, believe, and do. Language Teaching, 36, 81-109.

Borg, S. (2007). Research engagement in English language teaching. Teaching and Teacher Education, 23, 731-747. 
Borg, S. (2010). Language teacher research engagement. Language Teaching, 43, 391-429.

Borg, S. (2013). Teacher research in language teaching: A critical analysis. Cambridge: Cambridge University Press.

Borg, S., \& Sanchez, H. S. (Eds.). (2015). International perspectives on teacher research. Basingstoke, UK: Palgrave Macmillan.

Brumfit, C. J. (1995). Teacher professionalism and research. In G. Cook \& B. Seidlhofer (Eds.), Principle and Practice in Applied Linguistics (pp. 27-41). Oxford: Oxford University Press.

Burns, A. (2011). Action research in the field of second language teaching and learning. In E. Hinkel (Ed.), Handbook of research in second language teaching and learning (pp. 237-253). Vol. II. New York: Routledge/Taylor \& Francis.

Byrnes, H. (2000). Shaping the discourse of a practice: The role of linguistics and psychology in language teaching and learning. Modern Language Journal, 84, 472-494.

Byrnes, H. (2013). Editor's Introduction. Modern Language Journal, 97,105-108.

Byrnes, H. (2016). Notes from the editor: Celebrating 100 years of The Modern Language Journal. Modern Language Journal, 100 (Supplement 2016), 3-18.

Carter, A. (2015). Carter review of initial teacher training (ITT). London: Crown Copyright. Chapelle, C. (2007). Pedagogical implications in TESOL Quarterly? Yes, please! TESOL Quarterly, 41, 404-406.

Chubb, J., \& Watermeyer, R. (2016). Artifice or integrity in the marketization of research impact? Investigating the moral economy of (pathways to) impact statements within research funding proposals in the UK and Australia. Studies in Higher Education, 1-13.

http://dx.doi.org/10.1080/03075079.2016.1144182 
Coates, S., et al. (2011). Second report of the independent review of teachers' standards: Post-threshold, excellent teacher and advanced skills teacher standard. London: Crown Copyright.

Collins, L., \& Muñoz, C. (2016) The foreign language classroom: Current perspectives and future considerations, Modern Language Journal, 100 (Supplement 2016), 133-147.

Conway, J. M., \& Huffcutt, A. I. (2003). A review and evaluation of exploratory factor analysis practices in organizational research. Organizational Research Methods, 6 , $147-168$.

Cordingley, P. (2015). The contribution of research to teachers' professional learning and development. Oxford Review of Education, 41, 234-252.

Cordingley, P. (2004). Teachers using evidence: Using what we know about teaching and learning to reconceptualize evidence-based practice. In G. Thomas \& R. Pring (Eds.), Evidence-based practice in education (pp. 77-87). Maidenhead: Open University Press.

DfE (2015). Initial teacher training census for the academic year 2015 to 2016, England. London: Crown Copyright.

DfE. (2016). Educational excellence everywhere [white paper]. London: Crown Copyright. eLife (2017). List of journals publishing plain language summaries

\section{https://elifesciences.org/elife-news/plain-language-summaries-list-of-journals.}

Ellis, R. (2010). Second language acquisition, teacher education and language pedagogy. Language Teaching, 43, 182-201.

Ellis, R. (2012). Language teaching research and language pedagogy. Chichester, UK: John Wiley and Sons.

Ellis, R., \& Shintani, N. (2013). Exploring language pedagogy through second language acquisition research. London: Routledge. 
Field, A. (2013). Discovering statistics using IBM SPSS statistics. London: SAGE.

Furlong, J., Menter, I., Munn, P., Whitty, G., Hallgarten, J., \& Johnson, N. (2014). The role of research in teacher education: Reviewing the evidence. Interim report of the BERA-RSA Inquiry. London: BERA \& RSA

Great Lakes Center for Education Research and Practice (2017). Accessed 12 April 2017 from http://greatlakescenter.org/.

Hammersley, M. (2003). Can and should educational research be educative? Oxford Review of Education, 29, 3-25.

Hellerman, J. (Ed.). (2015). Definitions for applied linguistics [Special Issue]. Applied Linguistics, 36, 419-492.

Holbrook, J. (2012). Re-assessing the science - society relation: The case of the US National Science Foundation's broader impacts merit review criterion (1997-2011). Accessed 4 April 2017 from digital.library.unt.edu/ark:/67531/metadc77119/m1/1/.

Holbrook, J., Hrotic, S. (2013) Blue skies, iimpacts, and peer review. Roars Transactions: A Journal on Research Policy \& Evaluation 1 (1) DOI: http://dx.doi.org/10.13130/2282$\underline{5398 / 2914}$

Kiely, R. (2014). Connecting with teachers: The case for language teaching research in the social sciences. ELT Journal, 68, 442--450.

King, S., Pewsey, E., Shailes, S. (2017) Plain-language summaries of research: An inside guide to eLife digests. eLife, 6, e25410

Kubanyiova, M., \& Crookes, G. (2016). Re-envisioning the roles, tasks, and contributions of language teachers in the multilingual era of language education research and practice. Modern Language Journal, 100 (Supplement 2016), 117-132. 
Language Learning. (2016). Overview: Aims and scope. Accessed 15 April 2016 at http://onlinelibrary.wiley.com/journal/10.1111/(ISSN)14679922/homepage/ProductInformation.html

Lantolf, J. P. (2000). A century of language teaching research: Looking back and looking ahead. Modern Language Journal, 84, 467-471.

Lantolf, J. P. \& Poehner, M. E. (2015). Sociocultural theory and second language education: The pedagogical imperative. Routledge.

Larsen-Freeman, D. (2009). Prediction or retrodiction? The coming together of research and teaching. In C. M. Pearson, K. M. Losey, M. Pasquale, P. S. H. Bogart, \& R. S. Anderson (Eds.), Spotlight on research: A new beginning. The selected proceedings of the 2008 MITESOL conference. Raleigh, NC: LuLu.

Larsen-Freeman, D. (2015). Research into practice: Grammar learning and teaching. Language Teaching, 48, 263-280.

Lawes, S. (2003). What, when, how and why? Theory and foreign language teaching. Language Learning Journal, 28, 22-28.

Leat, D., Reid, A., \& Lofthouse, R. (2015). Teachers' experiences of engagement with and in educational research: What can be learned from teachers' views? Oxford Review of Education, 41, 270-286.

Lightbown, P. (2000). Anniversary article: Classroom SLA research and second language teaching. Applied Linguistics, 21, 431-462.

Long, M. (2000). Acquisition and teaching. In M. Byram (Ed.), Routledge encyclopaedia of language teaching and learning (pp. 5-7). London: Routledge.

Macaro, E. (2003). Second language teachers as second language classroom researchers. The Language Learning Journal, 27, 43-51. 
Macrory, G. (2015). Modern languages initial teacher education in England: The impact of school-based training. In T. Wright \& M. Beaumont (Eds.), Experiences of second language teacher education. London: Palgrave Macmillan.

Marsden, E., Mackey, A., \& Plonsky, L. (2016). The IRIS Repository: Advancing research practice and methodology. In A. Mackey \& E. Marsden (Eds.) Advancing methodology and practice: The IRIS Repository of Instruments for Research into Second Languages (pp. 1-21). New York: Routledge/Taylor \& Francis.

Marsden, E., Morgan-Short, K., Thompson, S., Abugaber, D. (under review). A synthesis of self-labelled replication practices in second language research. Language Learning.

Marsden, E., \& Torgerson, C. J. (2012). Single group, pre- and post- research designs: Some methodological concerns. Oxford Review of Education, 38, 583-616.

McNamara, O. (2002). Evidence-based practice through practice-based evidence. In O. McNamara (Ed.), Becoming an evidence-based practitioner (pp. 15-26). London: Routledge Falmer.

McMillan, J. H., \& Wergin, J. F. (2010). Understanding and evaluation education research (4th ed). Pearson Education.

Modern Language Journal. (2016). Overview: Aims and scope. Accessed 15 April 2016 at http://onlinelibrary.wiley.com/journal/10.1111/(ISSN)15404781/homepage/ProductInformation.html

Montgomery, C. \& Smith, L. C. (2015). Bridging the gap between researchers and practitioners. Die Unterrichtspraxis, 48, 100-113.

National Science Board (2011). Merit review criteria: Review and revisions. National Science Foundation. 
Norris, J. M., \& Manchón, R. M. (2012). Investigating L2 writing development from multiple perspectives: Issues in theory and research. In R. Manchón (Ed.), L2 writing development: Multiple perspectives (pp. 219-245). New York: Walter de Gruyter.

Ortega, L. (2005). Methodology, epistemology, and ethics in instructed SLA research: An introduction. Modern Language Journal, 89, 317-327.

Ortega, L. (2012). Language acquisition research for language teaching: Choosing between application and relevance. In B. Hinger, E. M. Unterrainer, \& D. Newby (Eds.), Sprachen lernen: Kompetenzen entwickeln? Performanzen (über)prüfen (pp. 24-38). Wien: Präsens Verlag.

Pachler, N. (2003). Foreign language teaching as an evidence-based profession? The Language Learning Journal, 27, 4-14.

Plonsky, L. (2013), Study quality in SLA: An assessment of designs, analyses, and reporting practices in quantitative L2 Research, Studies in Second Language Acquisition, 35, $655-687$.

Plonsky, L., \& Derrick, D. J. (2016). A meta-analysis of reliability coefficients in second language research. Modern Language Journal, 100, 538-553.

Plonsky, L., \& Gonulal, T. (2015). Methodological synthesis in quantitative L2 research: A review of reviews and a case study of exploratory factor analysis. Language Learning, 65(S1), 9-36.

Plonsky, L., \& Oswald, F. L. (2014). How big is 'big'? Interpreting effect sizes in L2 research. Language Learning, 64, 878-912.

Ratcliffe, M. (2004). Science education practitioners'views of research and its influence on their practice. In Evidence-based practice in science education (EPSE) research network report. York: Department of Educational Studies, University of York. 
Research Excellence Framework. (2011). Assessment framework and guidance on submissions. Accessed 6 January 2017 at http://www.ref.ac.uk/pubs/2011-02/

Rose, H. \& McKinley, J. (in press) The prevalence of pedagogy-related research in applied linguistics: Extending the debate. Applied Linguistics.

Sahlberg, P. (2010). The secret to Finland's success: Educating teachers (Research Brief). Stanford, CA: SCOPE.

Sanders, D., White, K., Sharp, C., \& Taggart, G. (2005). Evaluation of the NERF Bulletin trial. Phase two report. Slough: NFER.

Shkedi, A. (1998). Teachers' attitudes towards research: A challenge for qualitative researchers. International Journal of Qualitative Studies in Education, 11, 559-577.

Spada, N. (2015). SLA research and L2 pedagogy: Misapplications and questions of relevance. Language Teaching, 48, 69-81.

Studies in Second Language Acquisition. (2016). Studies in second language acquisition. Accessed 15 April 2016 at http://journals.cambridge.org/action/displayJournal?jid=SLA

Swain, H. (2014). Universities are still best place to train teachers, report says. The Guardian. Accessed 14 April 2016 at http://www.theguardian.com/education/2014/jan/14/universities-best-place-to-trainteachers-report-says

Tarling, R. (2009). Statistical modelling for social researchers. Oxford: Routledge.

Tatto, M. (2015). The role of research in the policy and practice of quality teacher education: an international review. Oxford Review of Education, 41, 171-201.

Thomson-Reuters. (2016). Social sciences citation index - Language and linguistics. Accessed 12 April 2016 at http://science.thomsonreuters.com/cgibin/jrnlst/jlresults.cgi?PC=SS\&SC=OT 
Trounson, A. (2014). ARC grants the focus for impact. Accessed 6 January 2017 at http://www.theaustralian.com.au/higher-education/arc-grants-the-focus-forimpact/news-story/8ae33db75a2bb3297dc13e7078b03f19

Universities UK. (2014). The impact of initial teacher training reforms on English higher education institutions (Higher Education in Focus series). London: Universities UK.

What Works Clearing House (2017). Accessed 12 April 2017 from https://ies.ed.gov/ncee/wwc/.

Williams, D., \& Coles, L. (2007). Teachers' approaches to finding and using research evidence: An information literacy perspective. Educational Research, 49, 185-206.

Winch, C., Oancea, A., \& Orchard, J. (2015). The contributions of educational research to teachers' professional learning: Philosophical understandings. Oxford Review of Education, 41, 202-216.

\section{APPENDIX A}

Items Analysed From the Full Survey

What is your position? (Please select all that apply):

- Student or trainee teacher

- Teacher

- Assistant head

- Advanced Skills Teacher (or similar specialist status)

- Head teacher

- Teacher educator/trainer

- School mentor for trainee teachers

- Local authority advisor 
- Currently enrolled on a university course (please specify)

- $\quad$ Other (please specify)

Length of experience as a qualified school teacher (excluding teaching / lecturing in HE):

- 0 years (currently training)

- 1-2 years

- $3-5$ years

- 6-10 years

- $10+$ years

$\underline{\text { Reading about research }}$

Have you ever read about research in a professional magazine or newsletter? $\quad$ Yes No

How many times have you read about research in a professional magazine or newsletter?

Please tell us approximately how many articles you have read and in which professional magazines or newsletters.

\begin{tabular}{lccccc} 
& 0 & 1 & $2-3$ & $4-7$ & $8+$ \\
\hline Name of newsletter/magazine _co newsletter/magazine & 0 & 0 & 0 & 0 & 0 \\
Name of ne & 0 & 0 & 0 & 0 & 0 \\
Name of newsletter/magazine & 0 & 0 & 0 & 0 & 0 \\
Name of newsletter/magazine & 0 & 0 & 0 & 0 & 0
\end{tabular}

Add another newsletter/magazine? Yes No

Have you ever read about research in a research journal? $\quad$ Yes No

How many times have you read about research in a research journal? 
Please tell us approximately how many articles you have read and in which journals.

\begin{tabular}{lccccc} 
& 0 & 1 & $2-3$ & $4-7$ & $8+$ \\
\hline Name of journal _- & 0 & 0 & 0 & 0 & 0 \\
Name of journal __- & 0 & 0 & 0 & 0 & 0 \\
Name of journal __ & 0 & 0 & 0 & 0 & 0 \\
Name of journal _- & 0 & 0 & 0 & 0 & 0
\end{tabular}

Add another journal? Yes No

$\underline{\text { Attending conferences }}$

Have you ever attended $\underline{\text { conferences }}$ where some research was presented? Yes No

Please tell us the name of the conference(s) and the approximate number of times you have attended.

\begin{tabular}{lcccc} 
& 0 & 1 & 2 & $3+$ \\
\hline Name of conference _- & 0 & 0 & 0 & 0 \\
Name of conference ___ & 0 & 0 & 0 & 0 \\
Name of conference ___ & 0 & 0 & 0 & 0 \\
Name of conference ___ & 0 & 0 & 0 & 0
\end{tabular}

Add another conference? $\quad$ Yes No

Have you ever attended professional development events where some research was presented?

Yes No

Please tell us who organised the professional development event(s) (e.g., ALL, local school cluster) and the number of events attended.

$\begin{array}{llll}0 & 1 & 2 & 3+\end{array}$




\begin{tabular}{lcccc}
\hline Organiser & 0 & 0 & 0 & 0 \\
Organiser & 0 & 0 & 0 & 0 \\
Organiser & 0 & 0 & 0 & 0 \\
Organiser & 0 & 0 & 0 & 0
\end{tabular}

\section{Amount of Time Spent on Research-Related Activities}

Roughly how much time in total have you invested I research related activities to date, not including any research undertaken for your undergraduate degree or your teaching qualification?

Please provide an approximate total that includes reading, listening to, discussing, and doing research.

In total, since I qualified as a teacher, I have spent . . .

- No time

- $1-4$ hours

- 1 day

- $2-5$ days

- $\quad 2-3$ weeks

- 4-8 weeks

- 8 weeks or more

$\underline{\text { Factors preventing engagement with research }}$

Please indicate the extent to which these factors prevent you from engaging in (more) research activities.

Remember: Research activities include reading, discussing, presenting, adopting research-informed practice and carrying out research.

$\begin{array}{lllll}0 & 25 & 50 & 75 & 100\end{array}$

Lack of time 
Regulation and guidance given at a national or local level

Research terminology is not easily understood

Lack of confidence (i.e., trust) in the research I read or hear about

Lack of professional development in the teaching practice that is researcher

My lack of authority to make decisions

Research is not relevant to my practice

No money available to fund visits to conferences

No money available to fund me to carry out research projects

Research does not see learning or teaching the way I do

My lack of interest in research

Unaware of resources where I can find out about research

Lack of awareness about what is and what is not research-based practice

My own teaching experience is sufficient

If you wish, please tell us in what way(s) you think research studies and findings could be made more accessible for practitioners.

In your opinion, is the research that you are aware of relevant to everyday classroom practice?

- Not at all relevant

- Somewhat relevant

- Very relevant

If you wish, please tell us in what ways research could be made more relevant to the classroom.

\section{APPENDIX B}

Items Analysed From the Short Survey 
In the last 12 months, how would you describe your main job?

- Primary teacher

- Secondary teacher

- Teacher educator

- Trainee teacher

- Advisor

- CPD provider

- Other (please specify)

$\underline{\text { Reading and hearing about research }}$

In the last 12 months, approximately how many times have you...

... read or heard something that mentions (i.e. refers indirectly to) research about FL learning and teaching?

- 0

- $1-5$

- $6-10$

- $11-15$

- $16-20$

- $20+$

... read or heard an original research report, i.e., a study written or presented by those who did the research? E.g, at a conference, in a journal, or book

- 0

- $1-2$

- 3-5

- 6-8

- $\quad 9-10$ 
- $11-15$

- $16+$

What prevents you from engaging with (more) research activities?

Please indicate the extent to which these factors prevent you from engaging in more research activities.

'Research activities' include: reading, discussing, hearing, or presenting research, consciously adopting research-informed practice, carrying out research.

Limited time

Limited funding

Limited access (to reports, events, journals, etc.)

My own knowledge, skills or training

Research isn't relevant to my work

Research isn't relevant to my work compared to other demands

Research isn't useful for my work

Other (optional) please specify 


\section{APPENDIX C}

Number of Respondents for Each Sub-section of the Surveys

Subsection of Survey

\begin{tabular}{rcccccc}
\cline { 3 - 7 } Full survey & $\begin{array}{c}\text { Total } \\
\text { Responses }\end{array}$ & $\begin{array}{c}\text { Reading About } \\
\text { Research }\end{array}$ & $\begin{array}{c}\text { Attending } \\
\text { Conferences }\end{array}$ & $\begin{array}{c}\text { Time Spent on } \\
\text { Research }\end{array}$ & $\begin{array}{c}\text { Preventing } \\
\text { Engagement }\end{array}$ & $\begin{array}{c}\text { Relevance of } \\
\text { Research }\end{array}$ \\
\hline SB & 135 & 135 & 135 & 123 & 119 & 119 \\
NSB & 48 & 48 & 48 & 45 & 43 & 43 \\
Total & 183 & 183 & 183 & 168 & 162 & 162 \\
\hline
\end{tabular}

\begin{tabular}{rccc} 
Short Survey & $\begin{array}{c}\text { Total } \\
\text { Responses }\end{array}$ & $\begin{array}{c}\text { Reading/Hearing } \\
\text { About Research }\end{array}$ & $\begin{array}{c}\text { Preventing } \\
\text { Engagement }\end{array}$ \\
\hline SB & 281 & 281 & 229 \\
NSB & 110 & 110 & 104 \\
Total & 391 & 391 & 333 \\
\hline
\end{tabular}

\section{APPENDIX D}

Respondents' Length of Teaching Experience (Full Survey)

\begin{tabular}{ccccccc} 
& $n$ & 0 years & $1-2$ years & $3-5$ years & $6-10$ years & $10+$ years \\
\hline SB & 135 & $0.70 \%$ & $11.10 \%$ & $16.30 \%$ & $14.10 \%$ & $57.80 \%$ \\
NSB & 48 & 0 & 0 & $6.30 \%$ & $16.70 \%$ & $77.10 \%$ \\
Total & 183 & $0.50 \%$ & $8.20 \%$ & $13.70 \%$ & $14.80 \%$ & $62.80 \%$ \\
\hline
\end{tabular}




\section{APPENDIX E}

Most Frequently Mentioned Conferences /Professional Development Events (Full Survey)

\begin{tabular}{lcc} 
& number of \\
Event type & mentions & $\%$ \\
\hline ALL $^{\mathrm{a}}$ regional meetings & 51 & 15.5 \\
ALL ${ }^{\mathrm{a}}$ Language World & 49 & 14.8 \\
University-based & 26 & 7.9 \\
Local school cluster-led & 24 & 7.3 \\
Local authority-led & 19 & 5.8 \\
CILT/SCILT & & \\
Primary Languages & 14 & 4.2 \\
Show & 13 & 3.9 \\
\hline Total (of 330 mentions) & 196 & 59.4
\end{tabular}

${ }^{a}$ Association for Language Learning

${ }^{\mathrm{b}}$ CILT = Centre for Information on Language Teaching, or National Centre for Language Teaching (Note:

England and Wales branches closed in 2010 and 2015); SCILT = Scotland's National Centre for Languages

\section{APPENDIX F}

Total Number of Times Respondents Reported Having About Research From a Policy Document/Document Sent to Schools (Full Survey)
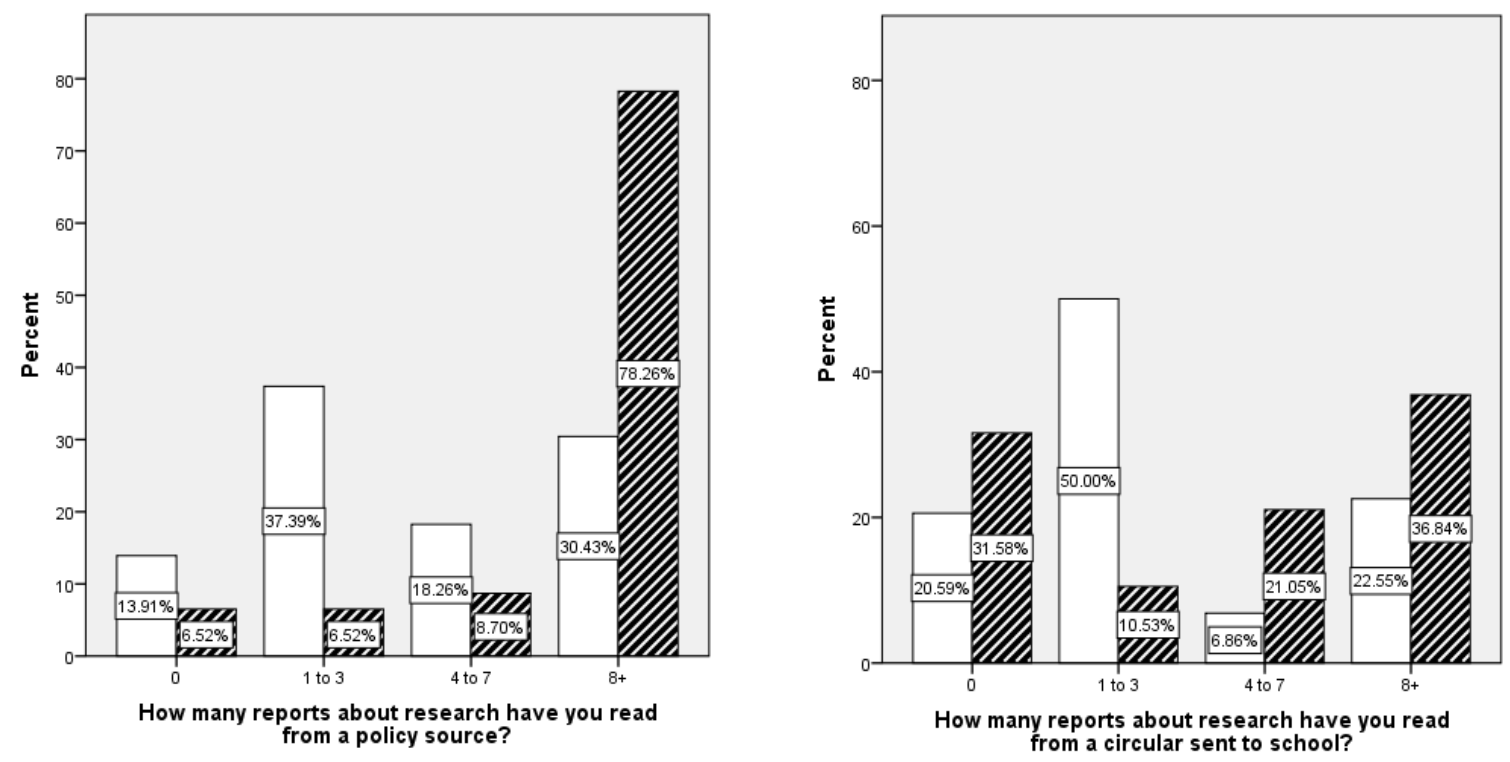
Appendix G

Proportions of References to FLA and the MLJ out of Total References to ISLA Journals

Mean \% citations (SD)

\begin{tabular}{rccccc} 
References to: & Full Dataset & LLJ & ALL Lang & Babel & NECTFL Review \\
\hline FLA & $6.46(16.79)$ & $3.30(10.97)$ & $0.47(2.78)$ & $4.57(16.30)$ & $32.42(25.27)$ \\
\hline MLJ & $10.27(21.19)$ & $7.51(14.11)$ & $1.41(7.32)$ & $15.54(29.72)$ & $28.03(28.35)$ \\
\hline
\end{tabular}

